University of South Florida

DIGITAL COMMONS

Digital Commons @ University of

@ UNIVERSITY OF SOUTH FLORIDA

South Florida

4-15-1994

\title{
The Effects of Temporal Variability of Mixed Layer Depth on Primary Productivity Around Bermuda
}

\author{
W. Paul Bissett \\ University of South Florida \\ Mark B. Meyers \\ Virginia Institute of Marine Science \\ John J. Walsh \\ University of South Florida, jwalsh@marine.usf.edu \\ Frank E. Muller-Karger \\ University of South Florida, carib@marine.usf.edu
}

Follow this and additional works at: https://digitalcommons.usf.edu/msc_facpub

Part of the Marine Biology Commons

\section{Scholar Commons Citation}

Bissett, W. Paul; Meyers, Mark B.; Walsh, John J.; and Muller-Karger, Frank E., "The Effects of Temporal Variability of Mixed Layer Depth on Primary Productivity Around Bermuda" (1994). Marine Science Faculty Publications. 71.

https://digitalcommons.usf.edu/msc_facpub/71

This Article is brought to you for free and open access by the College of Marine Science at Digital Commons @ University of South Florida. It has been accepted for inclusion in Marine Science Faculty Publications by an authorized administrator of Digital Commons @ University of South Florida. For more information, please contact digitalcommons@usf.edu. 


\title{
The effects of temporal variability of mixed layer depth on primary productivity around Bermuda
}

\author{
W. Paul Bissett, Mark B. Meyers, ${ }^{1}$ John J. Walsh, and Frank E. Müller-Karger \\ Department of Marine Science, University of South Florida, St. Petersburg
}

\begin{abstract}
Temporal variations in primary production and surface chlorophyll concentrations, as measured by ship and satellite around Bermuda, were simulated with a numerical model. In the upper $450 \mathrm{~m}$ of the water column, population dynamics of a size-fractionated phytoplankton community were forced by daily changes of wind, light, grazing stress, and nutrient availability. The temporal variations of production and chlorophyll were driven by changes in nutrient introduction to the euphotic zone due to both high- and low-frequency changes of the mixed layer depth within $32^{\circ}-34^{\circ} \mathrm{N}$, $62^{\circ}-64^{\circ} \mathrm{W}$ between 1979 and 1984 . Results from the model derived from high-frequency (case 1) changes in the mixed layer depth showed variations in primary production and peak chlorophyll concentrations when compared with results from the model derived from low-frequency (case 2) mixed layer depth changes. Incorporation of sizefractionated plankton state variables in the model led to greater seasonal resolution of measured primary production and vertical chlorophyll profiles. The findings of this study highlight the possible inadequacy of estimating primary production in the sea from data of low-frequency temporal resolution and oversimplified biological simulations.
\end{abstract}

\section{Introduction}

First-order estimates of the biological carbon fluxes in oceanic marine ecosystems are based on a variety of methods. These methods include radioisotope uptake [Menzel and Ryther, 1960; Prezelin and Glover, 1991; Lohrenz et al., 1992], time-averaged sedimentation [Eppley et al., 1983; Deuser, 1986; Martin et al., 1987; Altabet, 1989], nutrient depletion [Jenkins, 1988; Spitzer and Jenkins, 1989], and oxygen release rates [Jenkins and Goldman, 1985; Williams and Purdie, 1991] as well as satellite assessments [Eppley et al., 1985; Platt et al., 1991]. The list of problems associated with each approach is long and has been well documented [e.g., Platt et al., 1989]. However, it is clear, even within the range of error, that there are discrepancies between the fluxes derived from instantaneous uptake estimates and those of bulk property estimates.

These discrepancies between the various estimates are thought to arise in part from differences in the temporal resolution of the measurements [Harris, 1980; Platt and Harrison, 1985, 1986]. Any attempt to accurately reconcile these disparate estimates would require an experimental framework which integrates phytoplankton growth at high frequencies but over extended periods. Unfortunately, collection of data at high frequencies over long periods has proven to be difficult, leaving the problems of reconciliation without an effective experimental solution. However, computer simulations have the ability to run at different frequency scales and appear to be one method of exploring the

\footnotetext{
'Now at Virginia Institute of Marine Science, Gloucester Point. Copyright 1994 by the American Geophysical Union.

Paper number 93JC03154. 0148-0227/94/93JC-03154\$05.00
}

question of temporal resolution in the reconciliation of different productivity and flux estimates.

The question of parameterizing time scales accurately becomes of paramount importance when one is trying to simulate an ecological system [Platt et al., 1989]. Jenkins [1988] suggests that introduction of nutrients to the euphotic zone by mixing events in oligotrophic regions may occur over weeks or days. Yet few models incorporate such high-frequency nutrient injection in the open ocean (for examples of prior efforts at modeling the deep sea, see Wroblewski et al. [1988], Musgrave et al. [1988], Fasham et al. [1990], and Taylor et al. [1991]). One would expect these episodic events (i.e., wind and/or eddy events), to have a large effect on the amount of biogenic flux from the primary productivity in oceanic ecosystems [Eppley and Peterson, 1979; Klein and Coste, 1984]. Thus reconciliation of theory and observations may be aided by more accurate descriptions of the temporal variations in the physical environment simulated within oceanic models.

In addition, parameterizations of biological processes can be just as important as parameterizations of physical processes [Harris, 1980]. For example, a major simplification is the assumption of only single units of phytoplankton and zooplankton species, functional groups, or trophic levels within the simulated water column [Wroblewski et al., 1988; Walsh et al., 1989; Fasham et al., 1990; Taylor et al., 1991]. Such simplifications may preclude accurate assessment of carbon fluxes, since various classes of phytoplankton and zooplankton contribute differently to the downward transport of organic material [Longhurst, 1991; Walsh et al., 1991]. Species succession has been documented in oligstrophic waters [Menzel et al., 1963; Hulburt, 1990], and these different phytoplankton functional groups utilize and export nitrogen at different rates [Walsh et al., 1991; Gregg and Walsh, 1992]. Incorporation of additional phytoplankton 


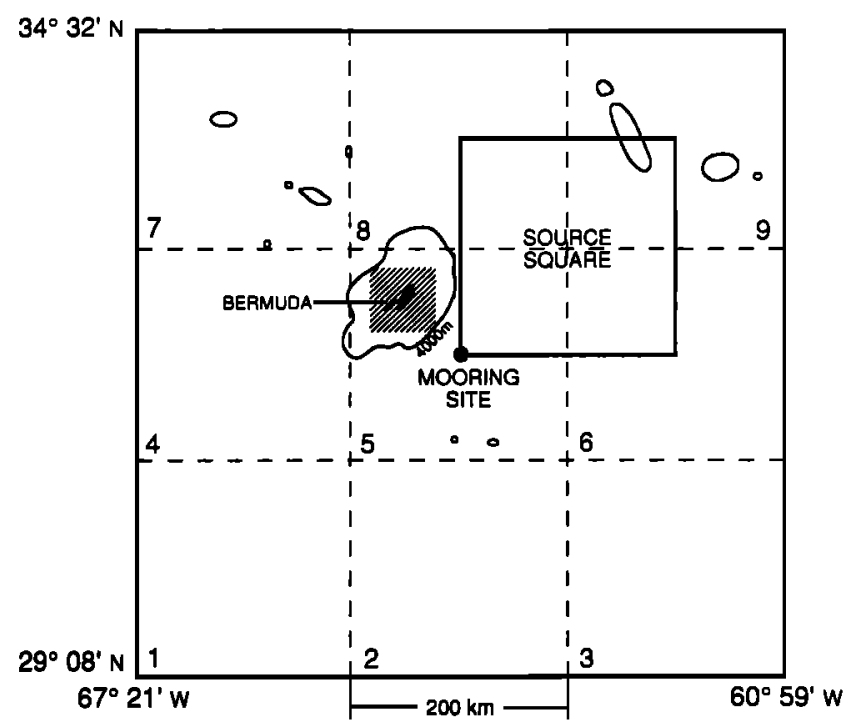

Figure 1. The study region of an oligotrophic ecosystem model near Bermuda.

species in a computer simulation should provide more robust comparisons to experimental data as well as some reconciliation between different estimates of productivity.

This work explores the ramifications of high-frequency variations of the mixed layer depth on relatively complex biological interactions within an oligotrophic ecosystem. It is based on a one-dimensional model of nitrogen uptake by two functional groups of phytoplankton in the Sargasso Sea near
Bermuda. The model was forced by daily, monthly, and interannual changes of the mixed layer depth in the Sargasso Sea from 1979 to 1984 . The model results were compared to results in published studies of depth-integrated primary production, nutrient and chlorophyll profiles, and sediment trap catches and to surface chlorophyll estimates from the coastal zone color scanner (CZCS).

\section{Methods}

\subsection{Surface Pigment Concentrations}

Estimates of surface pigment concentrations were derived from coastal zone color scanner images at 4-km resolution for 10 different regions of the Sargasso Sea from $28.6^{\circ}$ to $35.0^{\circ} \mathrm{N}$ and $61.0^{\circ}$ to $67.4^{\circ} \mathrm{W}$ (Figure 1). This same study region was chosen by Deuser et al. [1990] for determining the general direction of transport of biogenic sediments that arrived at a long-term deep-water sediment trap moored at $31^{\circ} 50^{\prime} \mathrm{N}, 64^{\circ} 10^{\prime} \mathrm{W}$ (Figure 1). The images were navigated and remapped to a cylindrical equidistant projection for the period January 1979 to December 1984. The algal pigment concentrations were derived according to the method of Gordon et al. [1983a, b].

In this analysis we focus on a time series of surface chlorophyll concentrations based on CZCS images within the Deuser et al. [1990] "source square," over $32^{\circ}-34^{\circ} \mathrm{N}$ and $62^{\circ}-64^{\circ} \mathrm{W}$ (Figure 1). We averaged pixels within this area for each day for which there were at least 25 pixels (of a possible 2500 pixels) of data. Missing data between the 441 valid daily images were linearly interpolated to produce the CZCS time series of Figure 2.

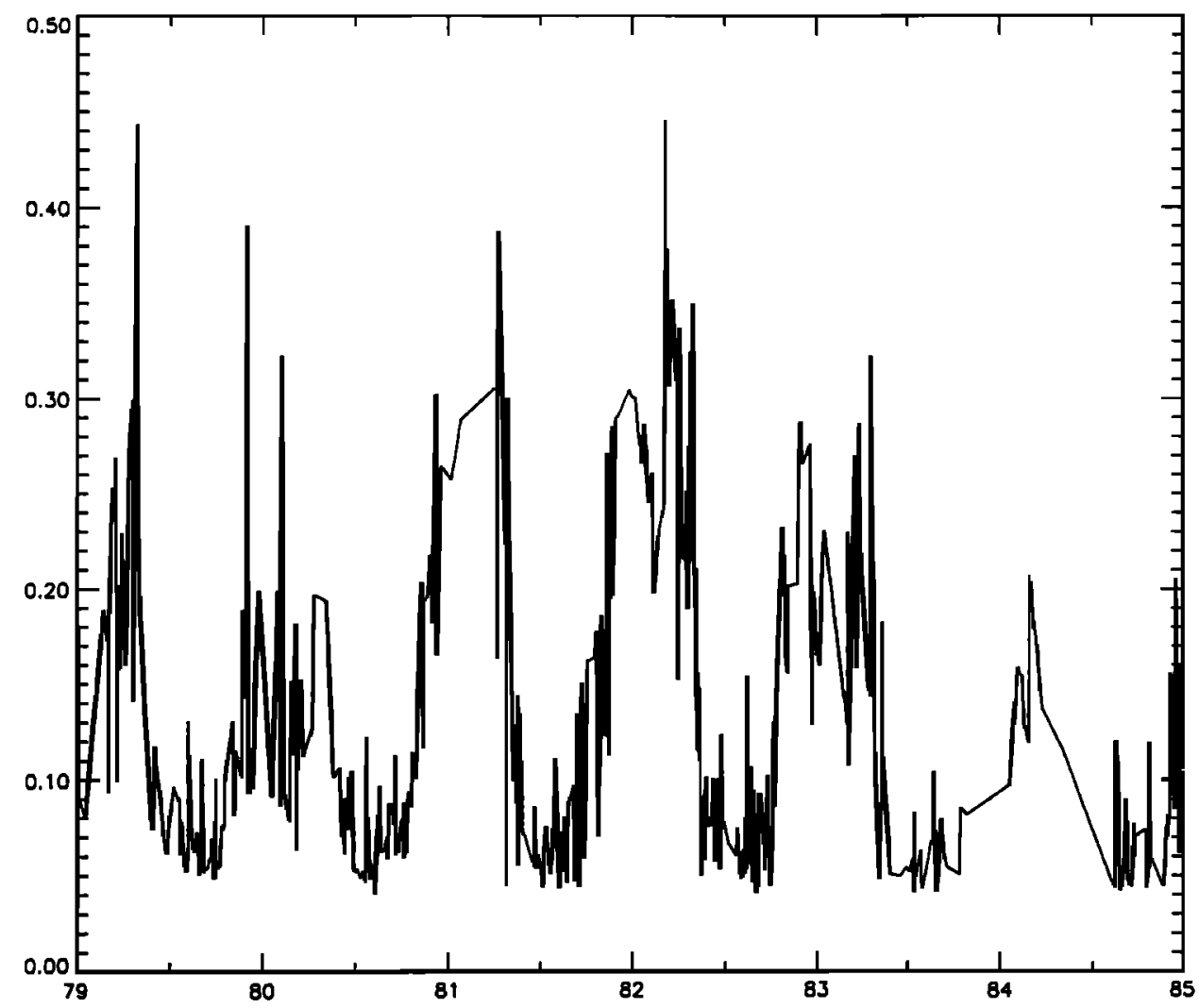

Figure 2. A time series of the CZCS estimate of total chlorophyll $a$ concentrations (1979-1984) for the area $32^{\circ}-34^{\circ} \mathrm{N}, 62^{\circ}-64^{\circ} \mathrm{W}$. 


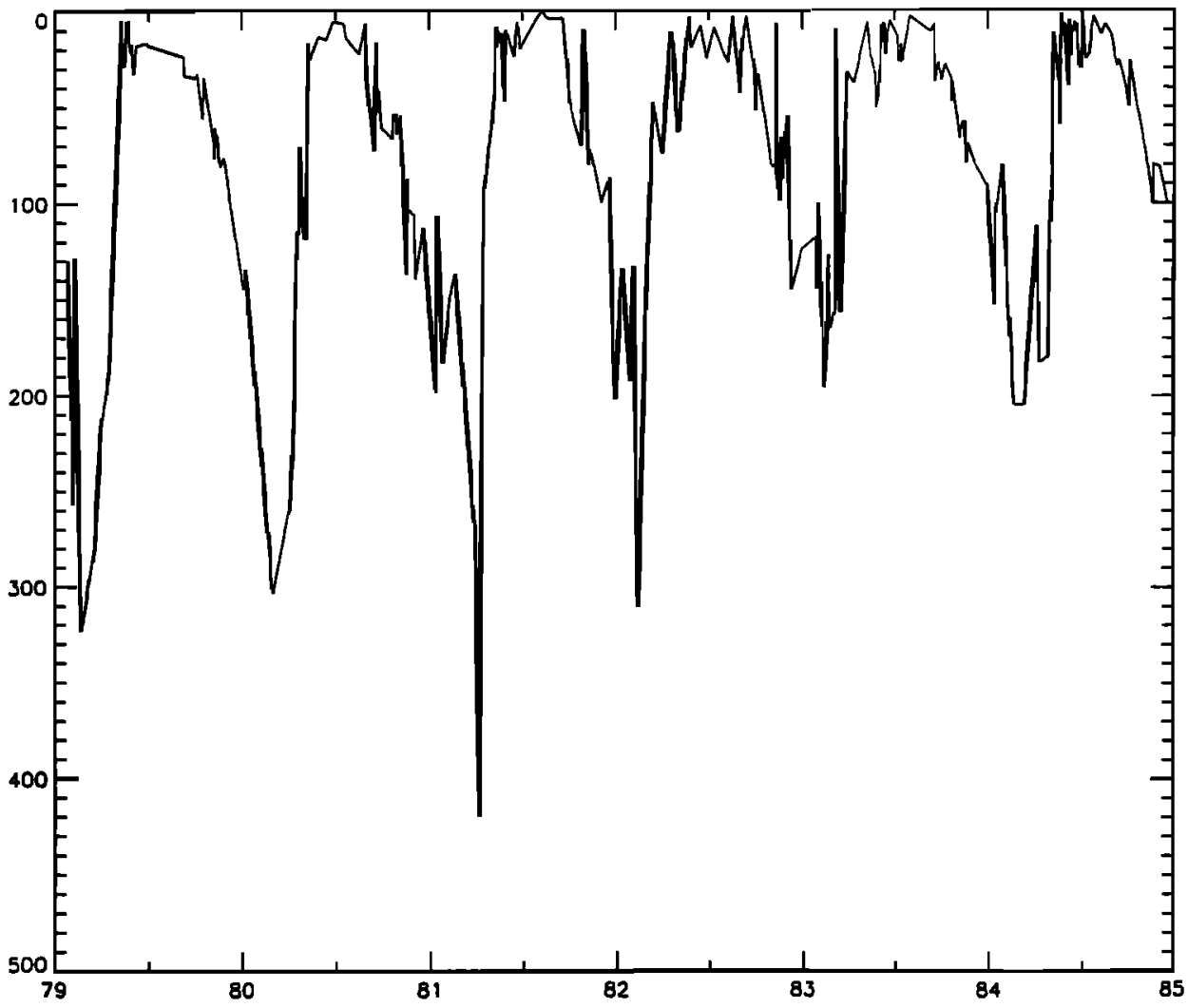

Figure 3. A time series of daily mixed layer depths from NODC data (case 1 model input).

\subsection{Mixed-Layer Depth}

A time series of mixed layer depths for the source square was also constructed from the National Oceanographic Data Center (NODC) temperature profiles [NODC, 1991]. Our extraction of post-1950 data for the source square yielded 7068 records. From these, 133 records were deleted when temperature increases of more than $0.5^{\circ} \mathrm{C}$ were encountered with increasing depth. Such editing, involving about $1.9 \%$ of the records, was comparable to the percentage of records eliminated by Levitus [1982] in his static stability check.

The temperature profiles between the surface and $500 \mathrm{~m}$ were interpolated to $1-\mathrm{m}$ depth intervals. The mixed layer depth was then determined as the depth of a $0.5^{\circ} \mathrm{C}$ change from the surface temperature. The daily mixed layer depths from January 1979 to December 1984 are plotted in Figure 3. Figure 4 shows the monthly average of these daily records compared to the climatology from Levitus [1982] in a $2^{\circ} \times 2^{\circ}$ square centered at $33^{\circ} \mathrm{N}, 63^{\circ} \mathrm{W}$. To test the ramifications of temporal variability of the physical habitat on both primary production and chlorophyll concentrations, case 1 of the model was first driven by the daily records of mixed-layer depth (Figure 3), while case 2 used the monthly averaged records (Figure 4).

\subsection{Simulation Description}

A one-dimensional model of daily plankton dynamics of carbon and nitrogen cycling over 45 levels in the upper $450 \mathrm{~m}$ $(\Delta z=10 \mathrm{~m})$ was applied at $33^{\circ} \mathrm{N}, 63^{\circ} \mathrm{W}$. The state equations were nonlinear partial differential equations for phytoplankton $\left(\boldsymbol{P}_{i}\right.$, where the subscript indicates more than one algal component, using chlorophyll as an index of biomass), nitrate $(N)$, and ammonium $(A)$. The forcing functions of maximum incident radiation $\left(I_{\max }\right)$ and wind speed $(W)$ were changed daily within a climatological annual cycle. Mixed layer depth $\left(h_{m}\right)$ was changed daily (case 1 ) and monthly (case 2) within interannual cycles over the period January 1979 to December 1984 (Figures 3 and 4). Table 1 lists the values of the various parameters used in our simulations, while a full description of the model's equations and parameters is provided in the appendix.

\section{Results}

One of the highlights of this model is the permanent coexistence of two phytoplankton functional groups. The phytoplankton assemblage changes with respect to the seasonal cycles of nutrients, light, and mixing. During typical winter and spring periods, the assemblage is dominated by netplankton, in contrast to typical summer periods, which are dominated by picoplankton (Plates 1 and 2). Having accomplished this coexistence over a variety of different mixing regimes, it was possible to test differences in the output using high- and low-frequency variations of the mixed layer depth, that is, case 1 , with daily mixed layer changes, versus case 2 , with monthly mixed layer changes.

The frequency and magnitude of mixed layer depth changes have a significant effect on depth-integrated primary production, as shown in the case 1 and case 2 results (Figures 5 and 6; Table 2). Comparison of the production from case 1 (Figure 5 ) with that of case 2 (Figure 6) shows the most obvious difference to be in the netplankton production cycle. Case 1 netplankton primary production displays 


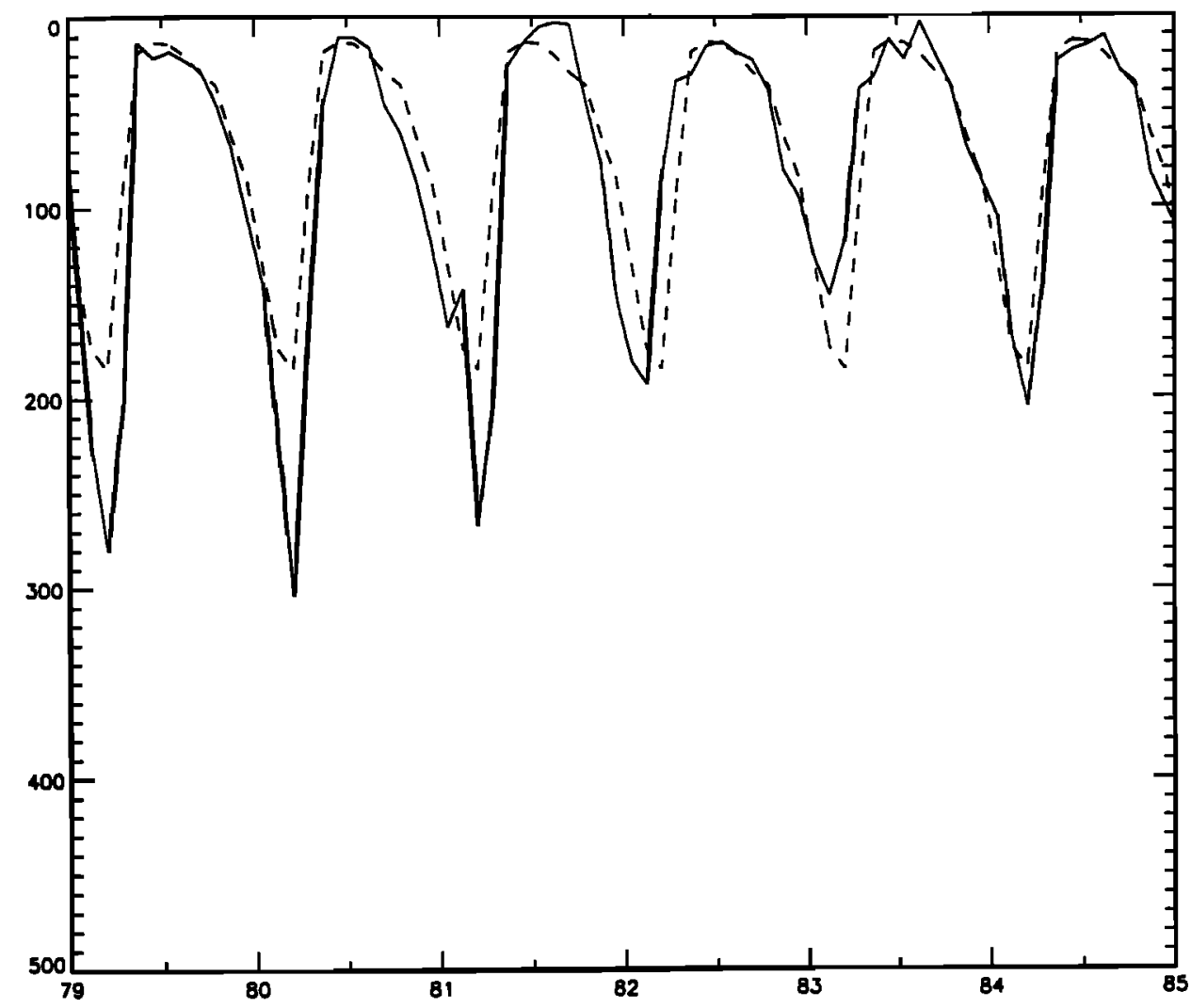

Figure 4. A time series of monthly averages of daily NODC mixed layer depth (case 2 model input, solid curve) and Levitus [1982] climatological mixed layer depth (dashed curve).

higher and more numerous peaks than primary production for case 2 netplankton. These patterns of netplankton production for case 1 and case 2 in Figures 5 and 6 resemble the earlier patterns of mixed layer depths in Figures 3 and 4 , respectively, as a consequence of the frequency and quantity of nutrient injection to the euphotic zone.

Annual, total, and new primary production (Table 2) were slightly higher on average for the daily mixed layer (case 1) than for the monthly mixed layer (case 2). Average total production over the 6 years was $118.9 \mathrm{~g} \mathrm{C} \mathrm{m}^{-2} \mathrm{yr}^{-1}$ for case 2 compared to $123.0 \mathrm{~g} \mathrm{C} \mathrm{m}^{-2} \mathrm{yr}^{-1}$ for case 1 , that is, a $3.4 \%$ increase. Average new production rates were 52.8 and $50.1 \mathrm{~g}$
$\mathrm{C} \mathrm{m}^{-2} \mathrm{yr}^{-1}$ for cases 1 and 2, respectively. This increase was due to a mean increase of $5.5 \%$ in the supply of $\mathrm{NO}_{3}$ to the euphotic zone, which resulted from the increase in temporal variability of the mixed-layer depth in case 1 . In the extreme during 1982, there were 24 and $15 \%$ rises in new and total production, respectively, for case 1 compared to case 2 (Table 2).

The larger difference between case 1 and case 2 annual primary productivity in 1982 shows the effects of smoothing the high-frequency mixed-layer depth changes over 1-month intervals. There were two peaks of $>0.7 \mathrm{mg}$ chlorophyll (Chl) $\mathrm{m}^{-3}$ in netplankton biomass for case 1 during early

Table 1. Model Biological Parameters

\begin{tabular}{|c|c|c|c|c|}
\hline Parameter & Symbol & Units & Netplankton & Picoplankton \\
\hline Maximum growth rate & $\mu \mathrm{m}$ & \multirow{2}{*}{$\begin{array}{c}\text { day }^{-1} \\
\mathrm{mg} \mathrm{C}(\mathrm{mg} \mathrm{Chl})^{-1} \mathrm{~h}^{-1}\end{array}$} & 2.773 & 1.386 \\
\hline & & & \multirow{2}{*}{0.072} & \multirow{2}{*}{0.12} \\
\hline Photosynthetic efficiency & $\alpha$ & $\mu \mathrm{E} \mathrm{m}^{-2} \mathrm{~s}^{-1}$ & & \\
\hline $\begin{array}{l}\text { Carbon:Chl } a \\
\mathrm{NO}_{3} \text { half-saturation }\end{array}$ & $\boldsymbol{k}_{\mathrm{s}}$ & $\begin{array}{l}\text { mg mg }{ }^{-1} \\
\mu \mathrm{mol} \mathrm{L}^{-1}\end{array}$ & $\begin{array}{l}50 \\
0.1\end{array}$ & $\begin{array}{l}30 \\
0.1\end{array}$ \\
\hline $\mathrm{NH}_{4}$ half-saturation & $\hat{k}_{A}^{N}$ & $\mu \mathrm{mol} \mathrm{L}{ }^{-1}$ & 0.05 & 0.05 \\
\hline $\mathrm{NO}_{3}$-uptake inhibition & $\Psi$ & $\mathrm{L} \mu \mathrm{mol}^{-1}$ & 1.50 & 1.50 \\
\hline Maximum grazing loss & $g_{m}$ & $\mathrm{mg} \mathrm{Chl} \mathrm{m}{ }^{-3} h^{-1}$ & 0.0139 & $0.0150^{*}$ \\
\hline Grazing half-saturation & $\begin{array}{l}g_{0} \\
k_{g}\end{array}$ & $\mathrm{mg} \mathrm{Chl} \mathrm{m} \mathrm{m}^{-3}$ & 1.0 & $\mathbf{N A} \dagger$ \\
\hline Recycling efficiency & $\varepsilon$ & (none) & 0.5 & 0.8 \\
\hline Particle settling rate & $w_{g}$ & $\mathrm{~m} \mathrm{~d}^{-1}$ & 1.5 & 0.0 \\
\hline
\end{tabular}

*This value is in units of reciprocal hours; that is, it is a Chl-specific loss rate. See text. †NA, not applicable. 


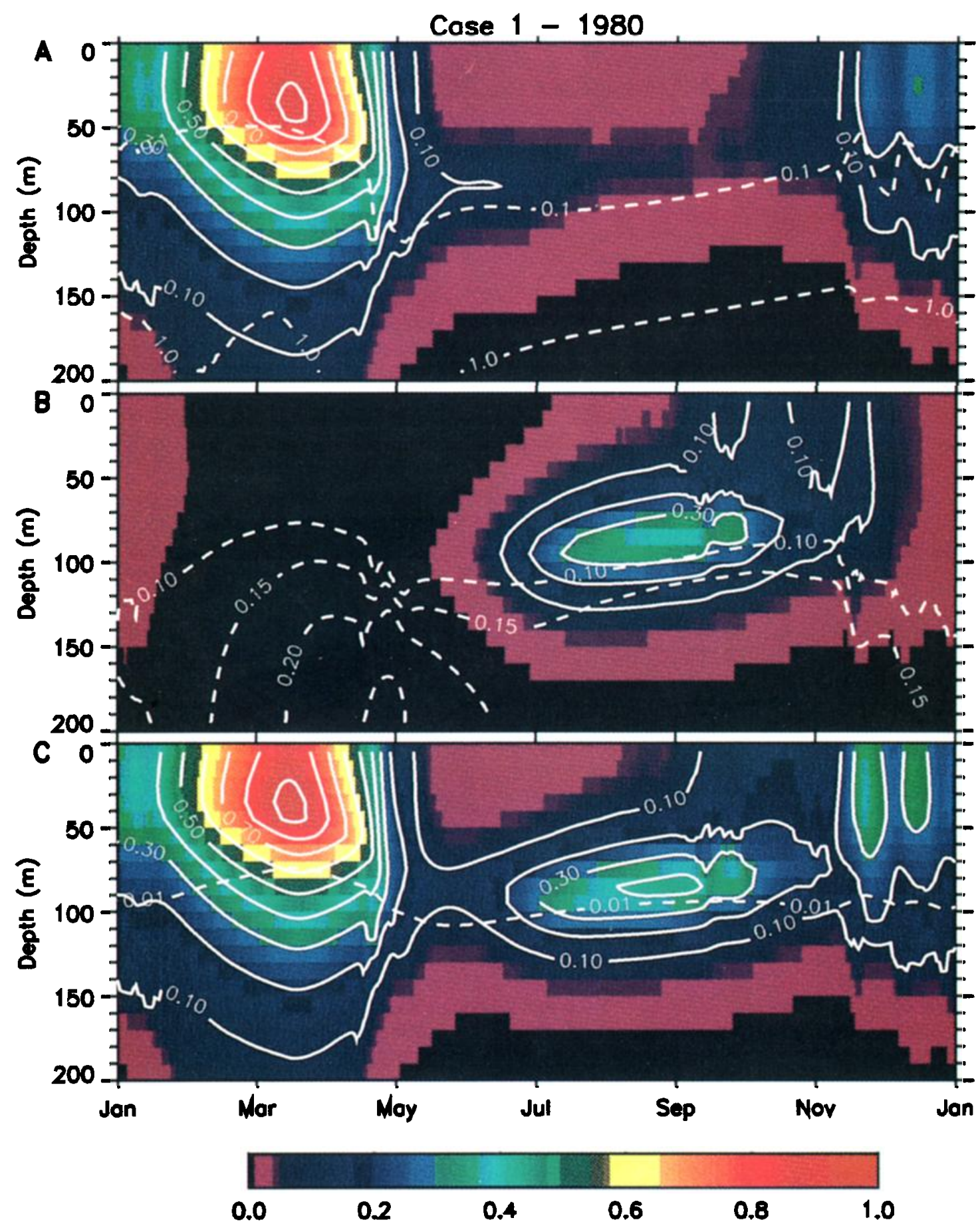

Plate 1. The 1980 case 1 time series of (a) netplankton (solid curve) and nitrate (dashed curve), (b) picoplankton (solid curve) and ammonium (dashed curve), and (c) total chlorophyll (solid curve) and percent photosynthetically active radiation (dashed curve).

1982 , both of which were higher in magnitude than the peak of $\sim 0.4 \mathrm{mg} \mathrm{Chl} \mathrm{m}{ }^{-3}$ for case 2 netplankton chlorophyll. In addition, the timing of the peaks of the blooms between the two cases was different (this can also be seen in the differences in peaks of primary production between case 1 and case 2 for 1982, figures 5 and 6). As a result of the lower netplankton concentrations, the picoplankton bloom in case 2 began earlier, lasted longer, and had a higher amount of chlorophyll biomass.

These differences in production and biomass between the functional groups as a result of differences in interannual mixing illuminate the dynamics of this more complex simulation of an oligotrophic ecosystem. For example, between two different years in the period 1980 to 1983 for case 1 (Plates 1 and 2), the respective nitrate fluxes into the euphotic zone fell $\sim 32 \%$ (Table 3). The lower influx of 1983 resulted from a decrease both in the maximum wintertime depth of the mixed layer and in the duration of the deep mixing (Figure 3). Combined total primary production, however, fell by only $19 \%$ (Table 2 ), owing to the changing structure of the 


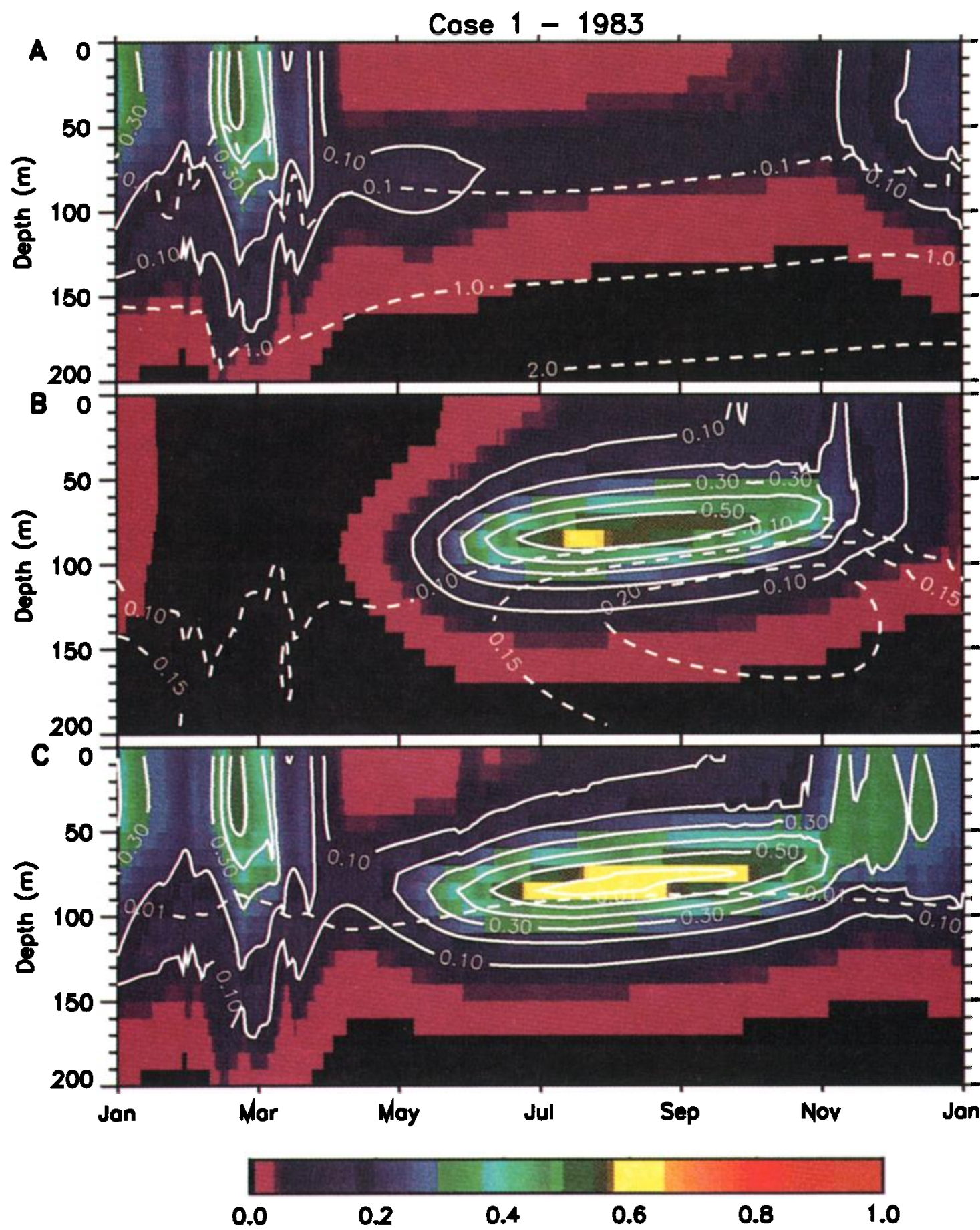

Plate 2. The 1983 case 1 time series of (a) netplankton (solid curve) and nitrate (dashed curve), (b) picoplankton (solid curve) and ammonium (dashed curve), and (c) total chlorophyll (solid curve) and percent photosynthetically active radiation (dashed curve).

phytoplankton assemblage. The change in netplankton total production over this period was $-42 \%$, but picoplankton total production actually increased by $83 \%$. Contours of netplankton chlorophyll, picoplankton chlorophyll, and total chlorophyll concentrations during 1980 and 1983 (Plates 1 and 2) show this changing phytoplankton assemblage.

These results demonstrate the temporal variance in chlorophyll biomass for each functional group and their total, resulting from interannual variations in the mixed layer structure (Figure 3 ). The relatively deep mixing in the late winter-early spring of 1980 introduced a substantially larger amount of nitrate into the euphoiic zone than did the shallower mixing of 1983. Plate 1 shows the anticipated rise in chlorophyll, dominated by the netplankton at concentrations of $>0.9$

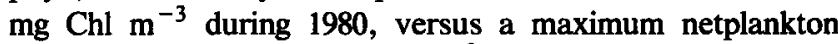
concentration of $>0.4 \mathrm{mg} \mathrm{Chl} \mathrm{m}^{-3}$ during 1983 (Plate 2).

In the summer of each year, a deep chlorophyll maximum occurs around a depth of $80 \mathrm{~m}$. The dominant functional group at this time in the model is the picoplankton, which is an expected result, given their higher efficiency at harvesting 


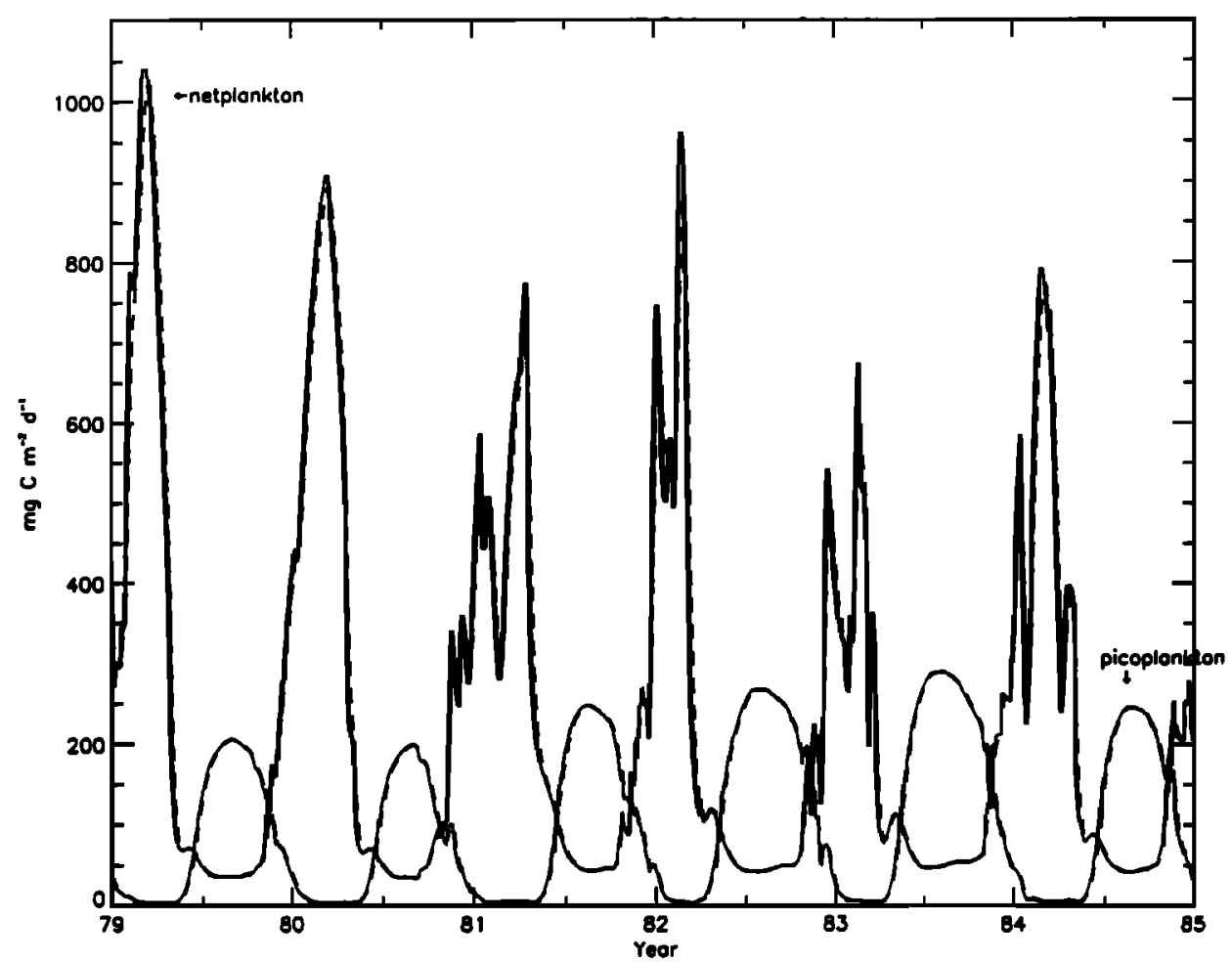

Figure 5. Time series of depth-integrated primary production of netplankton and picoplankton (solid curves) and their grazing losses (dashed curves) within a daily mixed layer (case 1).

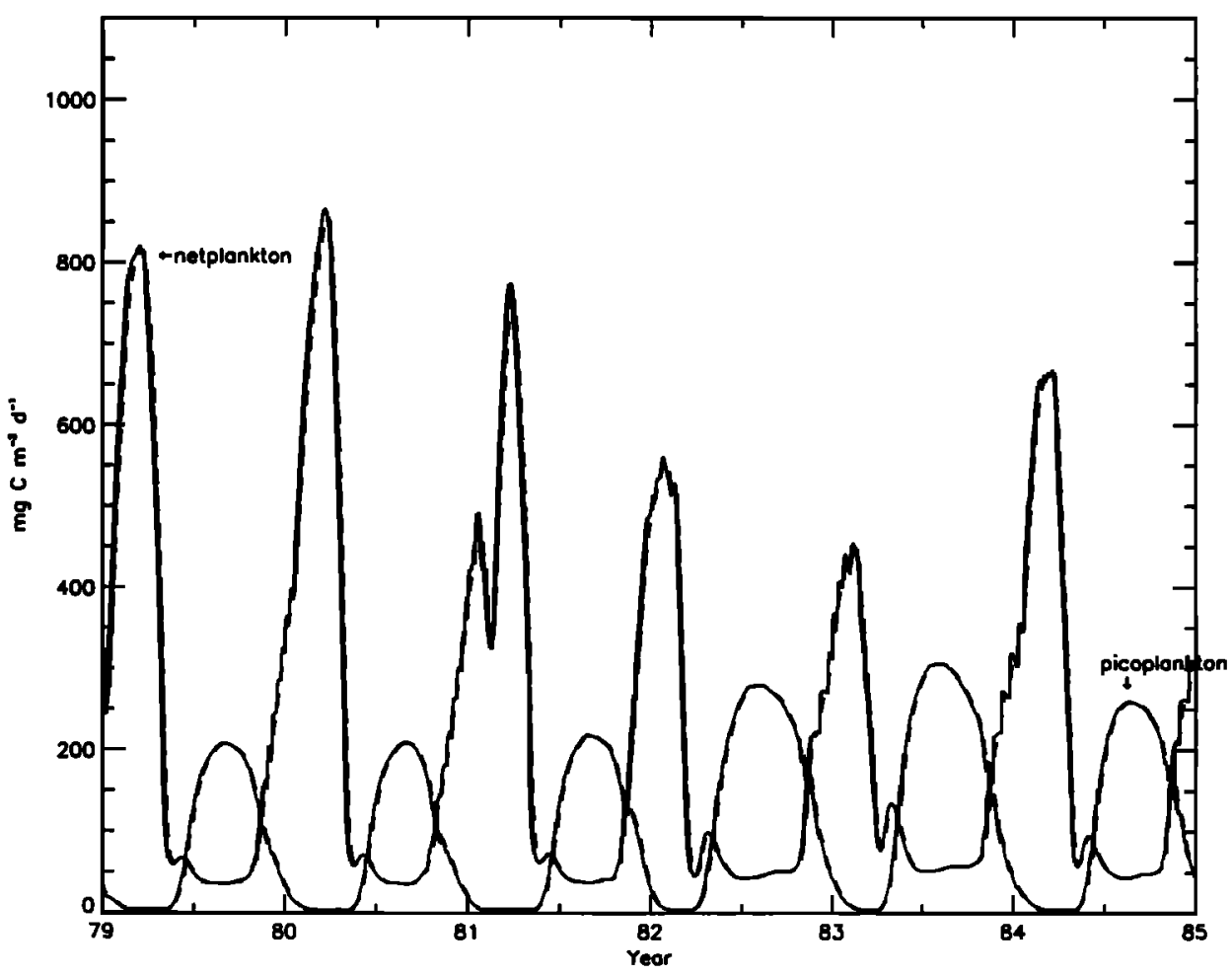

Figure 6. Time series of depth-integrated primary production of netplankton and picoplankton (solid curves) and their grazing losses (dashed curves) within a monthly mixed layer (case 2 ). 
Table 2. Simulated Yearly Variations in Production as a Result of NODC Daily and Monthly Mixed Layer Input

\begin{tabular}{|c|c|c|c|c|c|c|c|c|c|}
\hline \multirow[b]{2}{*}{ Year } & \multicolumn{3}{|c|}{ Netplankton } & \multicolumn{3}{|c|}{ Picoplankton } & \multicolumn{3}{|c|}{ Combined } \\
\hline & New* & Total* & $f$ ratio, $\%$ & New & Total & $f$ ratio, $\%$ & New & Total & $f$ ratio, \% \\
\hline \multicolumn{10}{|c|}{ NODC Daily Mixed Layer: Case 1} \\
\hline 1979 & 49.8 & 103.5 & 48.1 & 9.9 & 28.3 & 34.9 & 59.7 & 131.8 & 45.3 \\
\hline 1980 & 51.1 & 107.5 & 47.6 & 8.9 & 24.5 & 36.5 & 60.1 & 132.0 & 45.5 \\
\hline 1981 & 42.1 & 90.9 & 46.3 & 11.6 & 31.9 & 36.4 & 53.8 & 122.8 & 43.8 \\
\hline 1982 & 37.0 & 83.3 & 44.4 & 14.6 & 41.5 & 35.1 & 51.6 & 124.8 & 41.3 \\
\hline 1983 & 25.1 & 62.7 & 40.0 & 15.9 & 44.7 & 35.7 & 41.0 & 107.4 & 38.2 \\
\hline 1984 & 38.6 & 86.7 & 44.5 & 11.9 & 32.3 & 37.0 & 50.6 & 119.1 & 42.5 \\
\hline Mean & 40.6 & 89.1 & 45.2 & 12.1 & 33.9 & 35.9 & 52.8 & 123.0 & 42.8 \\
\hline Range & 26.1 & 44.8 & 8.1 & 7.0 & 20.2 & 2.0 & 19.0 & 24.5 & 7.3 \\
\hline Chg,$+ \%$ & 25.8 & 20.6 & 6.6 & 31.3 & 32.0 & 2.9 & 13.8 & 7.3 & 6.4 \\
\hline Chg -, \% & -38.3 & -29.6 & -11.4 & -26.5 & -27.8 & -2.8 & -22.3 & -12.6 & -10.7 \\
\hline \multicolumn{10}{|c|}{ NODC Monthly Mixed Layer: Case 2} \\
\hline 1979 & 45.0 & 95.7 & 47.0 & 10.0 & 28.0 & 35.8 & 55.0 & 123.7 & 44.5 \\
\hline 1980 & 48.1 & 101.3 & 47.5 & 9.5 & 26.3 & 36.0 & 57.5 & 127.6 & 45.1 \\
\hline 1981 & 42.7 & 91.5 & 46.6 & 10.8 & 29.3 & 36.7 & 53.4 & 120.8 & 44.2 \\
\hline 1982 & 25.6 & 63.9 & 40.0 & 16.2 & 45.4 & 35.6 & 41.7 & 109.3 & 38.2 \\
\hline 1983 & 25.3 & 63.2 & 40.0 & 17.2 & 47.7 & 36.0 & 42.5 & 110.9 & 38.3 \\
\hline 1984 & 37.3 & 84.6 & 44.1 & 13.4 & 36.7 & 36.5 & 50.7 & 121.3 & 41.8 \\
\hline Mean & 37.3 & 83.4 & 44.2 & 12.8 & 35.5 & 36.1 & 50.1 & 118.9 & 42.0 \\
\hline Range & 22.8 & 38.1 & 7.4 & 7.7 & 21.4 & 1.1 & 15.8 & 18.3 & 6.9 \\
\hline Chg +, \% & 28.8 & 21.5 & 7.4 & 33.8 & 34.1 & 1.6 & 14.8 & 7.3 & 7.4 \\
\hline Chg -, \% & -32.2 & -24.2 & -9.5 & -26.2 & -26.1 & -1.3 & -16.8 & -8.1 & -9.1 \\
\hline
\end{tabular}

Here, chg + , positive change; chg - , negative change.

*Values are in grams $\mathrm{C}$ per square meter per year.

low light (Table 1) and the greater availability of nutrients at the base of the euphotic zone. The intensity of the picoplankton chlorophyll maximum is inversely related to the magnitude of the netplankton spring bloom $\left(>0.3 \mathrm{mg} \mathrm{Chl} \mathrm{m}^{-3}\right.$ in 1980 versus $>0.5 \mathrm{mg} \mathrm{Chl} \mathrm{m}^{-3}$ in 1983) owing to competition for resources between the functional groups. Simulated cell abundances are similar to cell abundance studies in the region, after the amount of chlorophyll $\mathrm{m}^{-3}$ is converted to number of cells per cubic meter [Olson et al., 1990]. Picoplankton always dominate numerically in the simulations and are usually $>90 \%$ of the total cells.

A pattern emerges of relatively small variance in the combined total and new production of the phytoplankton community compared to the variance of production for indi-

Table 3. Nitrogen Export at $450 \mathrm{~m}$ Versus Nitrate-Based Production

\begin{tabular}{|c|c|c|c|c|c|c|c|c|c|c|c|}
\hline \multirow[b]{2}{*}{ Year } & \multicolumn{3}{|c|}{ Netplankton } & \multicolumn{3}{|c|}{ Picoplankton } & \multirow{2}{*}{$\begin{array}{l}\text { Total } \\
\text { Grazing } \\
\text { Export }\end{array}$} & \multirow{2}{*}{$\begin{array}{l}\text { Total } \\
\mathrm{NH}_{4} \\
\text { Flux }\end{array}$} & \multirow{2}{*}{$\begin{array}{c}\text { Total } \\
\text { Diffusive }+ \\
\text { Sediment }\end{array}$} & \multirow{2}{*}{$\begin{array}{c}\text { Total } \\
\text { Nitrogen } \\
\text { Export }\end{array}$} & \multirow{2}{*}{$\begin{array}{c}\text { Total } \\
\text { Nitrate } \\
\text { Production }\end{array}$} \\
\hline & Grazing & $\begin{array}{c}\text { Grazing } \\
\text { Export }\end{array}$ & $\begin{array}{c}\text { Diffusive }+ \\
\text { Sediment }\end{array}$ & Grazing & $\begin{array}{c}\text { Grazing } \\
\text { Export }\end{array}$ & $\begin{array}{c}\text { Diffusive }+ \\
\text { Sediment }\end{array}$ & & & & & \\
\hline \multicolumn{12}{|c|}{ NODC Daily Mixed Layer Runs: Case I } \\
\hline 1979 & 1.298 & 0.649 & 0.00042 & 0.356 & 0.071 & 0.000016 & 0.720 & 0.0232 & 0.00044 & 0.744 & 0.751 \\
\hline 1980 & 1.355 & 0.677 & 0.00042 & 0.308 & 0.062 & 0.000016 & 0.739 & 0.0231 & 0.00044 & 0.763 & 0.756 \\
\hline 1981 & 1.133 & 0.567 & 0.00043 & 0.400 & 0.080 & 0.000017 & 0.647 & 0.0179 & 0.00044 & 0.665 & 0.676 \\
\hline 1982 & 1.049 & 0.524 & 0.00041 & 0.522 & 0.104 & 0.000015 & 0.629 & 0.0176 & 0.00043 & 0.647 & 0.649 \\
\hline 1983 & 0.799 & 0.399 & 0.00041 & 0.562 & 0.112 & 0.000015 & 0.512 & 0.0152 & 0.00042 & 0.527 & 0.516 \\
\hline 1984 & 1.096 & 0.548 & 0.00041 & 0.407 & 0.081 & 0.000015 & 0.629 & 0.0155 & 0.00043 & 0.645 & 0.636 \\
\hline Mean & 1.122 & 0.561 & 0.00042 & 0.426 & 0.085 & 0.000016 & 0.646 & 0.0188 & 0.00043 & 0.665 & 0.664 \\
\hline \multicolumn{12}{|c|}{ NODC Monthly Mixed Layer Runs: Case 2} \\
\hline 1979 & 1.203 & 0.601 & 0.00042 & 0.352 & 0.070 & 0.000157 & 0.672 & 0.0195 & 0.00057 & 0.692 & 0.692 \\
\hline 1980 & 1.270 & 0.635 & 0.00042 & 0.331 & 0.066 & 0.000160 & 0.701 & 0.0203 & 0.00058 & 0.722 & 0.724 \\
\hline 1981 & 1.143 & 0.572 & 0.00041 & 0.368 & 0.074 & 0.000153 & 0.645 & 0.0168 & 0.00057 & 0.663 & 0.672 \\
\hline 1982 & 0.814 & 0.407 & 0.00041 & 0.570 & 0.114 & 0.000149 & 0.521 & 0.0146 & 0.00056 & 0.536 & 0.525 \\
\hline 1983 & 0.795 & 0.398 & 0.00041 & 0.599 & 0.120 & 0.000146 & 0.518 & 0.0141 & 0.00056 & 0.532 & 0.534 \\
\hline 1984 & 1.064 & 0.532 & 0.00041 & 0.461 & 0.092 & 0.000146 & 0.624 & 0.0156 & 0.00056 & 0.641 & 0.637 \\
\hline Mean & 1.048 & 0.524 & 0.00041 & 0.447 & 0.089 & 0.000152 & 0.614 & 0.0168 & 0.00056 & 0.631 & 0.631 \\
\hline
\end{tabular}

Values are in moles $\mathrm{N}$ per square meter per year. 


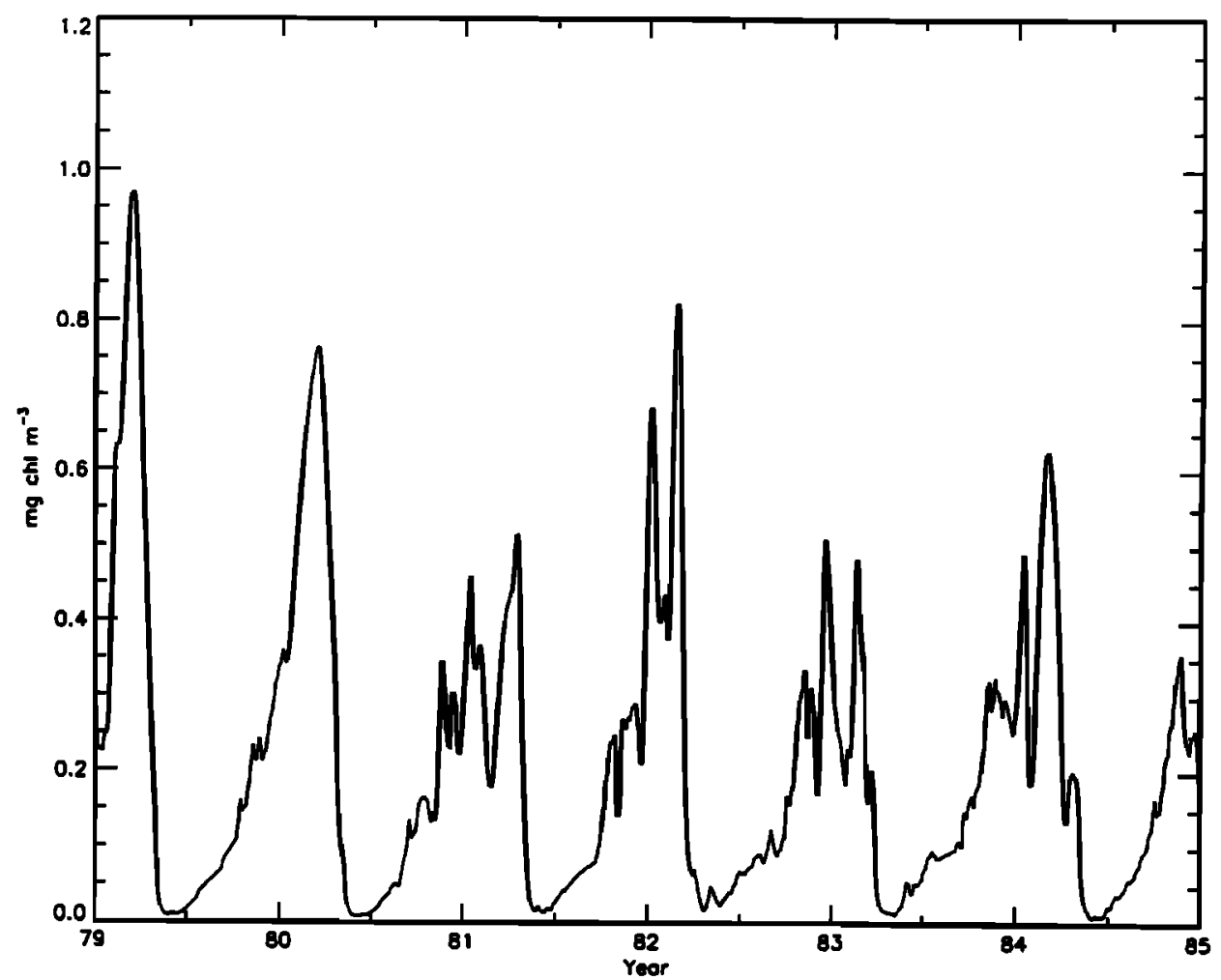

Figure 7. A time series of the case 1 simulated estimate of the total surface chlorophyll concentrations (1979-1984).

vidual functional groups. An increase of nitrate supply to the euphotic zone will lead to greater new and total production by netplankton but at the expense of picoplankton production (Table 2). One phytoplankton functional group is thus balanced against the other as they compete for light and nutrient resources and are differentially grazed by higher trophic levels.

While there is a small time lag in the grazing pressure (more pronounced for the netplankton), depth-integrated grazing closely follows photosynthesis (Figures 5 and 6). Grazing is the most important loss process, accounting for $97.5 \%$ of the total nitrogen export (Table 3) at $450 \mathrm{~m}$. Sinking and downward diffusion of phytoplankton cells account for $<0.1 \%$ of the total nitrogen export. The remaining export is the diffusion of $\mathrm{NH}_{4}$ because of the zero boundary condition of ammonium at $450 \mathrm{~m}$ (see the appendix).

The timing of the CZCS-derived (Figure 2) and simulated case 1 (Figure 7) seasonal cycles of total chlorophyll biomass are very similar, but the maximum concentration (during the spring bloom) is higher in the model, that is, $\sim 1.07$ versus $\sim 0.45 \mathrm{mg} \mathrm{Chl} \mathrm{m}^{-3}$. This discrepancy is higher than the 30 to 40\% error estimates for CZCS images [Gordon et al., 1983a].

\section{Discussion}

\subsection{CZCS Observations}

Convective overturning and ensuing phytoplankton blooms were postulated to be functions of atmospheric conditions in the Sargasso Sea over 30 years ago [Menzel and Ryther, 1960]. In the model described here, the depth and frequency of the convective overturn of the water column do indeed affect the amounts of nutrient supply, new and total primary productions (Table 2 ), and resultant chlo- rophyll concentrations (Plates 1 and 2) of the two phytoplankton size classes.

The surface chlorophyll concentrations from the simulation (Figure 7) follow the same seasonal pattern of the CZCS images (Figure 2); however, the magnitude of the simulated chlorophyll concentration is higher. One possible explanation for this may be the fixed carbon to chlorophyll ratio of 50:1 for netplankton (Table 1). This ratio may be too low for the surface waters of oligotrophic regions. Diatoms (netplankton in our simulation) are found throughout the euphotic zone, so we chose a mean carbon to chlorophyll ratio. In retrospect, a variable carbon to chlorophyll ratio may have been a better representation and will be attempted in the future. Since growth at the surface is limited by nitrogen, total carbon production is expected to be unaffected.

The differences between the minimal simulated and CZCS concentrations, 0.02 to $0.04 \mathrm{mg} \mathrm{Chl} \mathrm{m}^{-3}$ (Figure 8), result from the sharp declines of chlorophyll concentrations during the change of functional group dominance following the simulated spring bloom. This shifting of dominance may be an oversimplification in the present model, since more than two functional groups of phytoplankton exist in the real world. By August-September, the simulated surface chlorophyll again matches the CZCS estimates, when the picoplankton populations level off (Plates $1 \mathrm{~b}$ and $2 \mathrm{~b}$ ). A smoother transition between the dominance of netplankton and picoplankton by the inclusion of other functional groups, of phytoplankton might provide better fidelity between the minimum simulated surface chlorophyll concentrations and those estimated from the CZCS.

Another potential source of error between the simulation results and the CZCS images is our method of deriving 


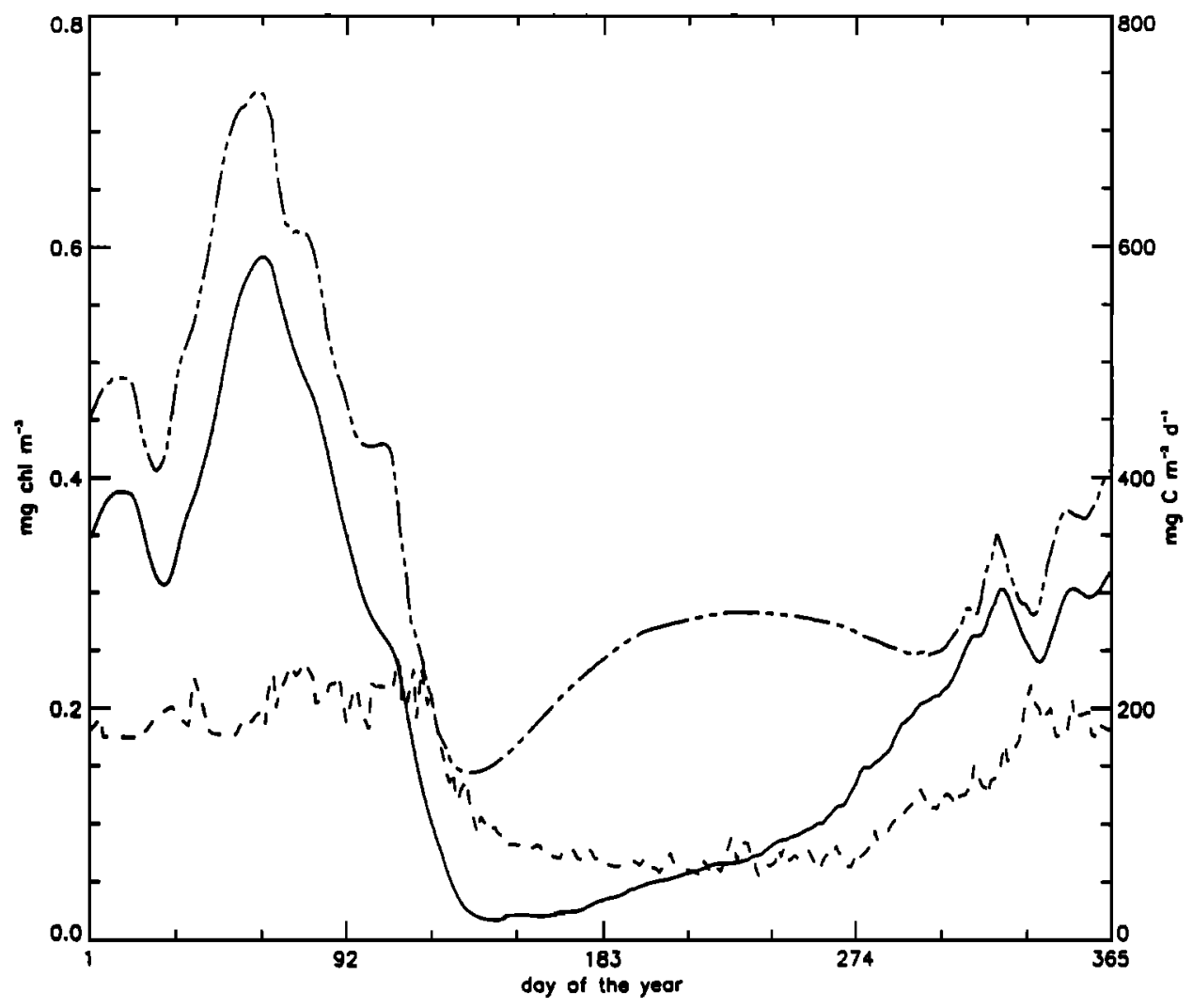

Figure 8. Time series of case 1 mean total surface chlorophyll (solid curve, left-hand scale), CZCSestimated chlorophyll (dashed curve, left-hand scale), and case 1 mean primary production (dot-dash curve, right-hand scale).

changes of the mixed layer depth. The daily mixed layer depths were linearly interpolated between those dates with NODC temperature profiles. This calculation may not be a true representation of the physical history of the water column and may distort the model's chlorophyll stocks, since the mixed layer depth affects the amount of nutrient injection to the euphotic zone. The nature of satellite sampling probably affected the information from the CZCS images as well. Both the mixed layer depth and the CZCS estimate had skewed distributions, with means of $65.4 \mathrm{~m}$ and $0.12 \mathrm{mg} \mathrm{Chl} \mathrm{m} \mathrm{m}^{-3}$ and medians of $39 \mathrm{~m}$ and $0.09 \mathrm{mg} \mathrm{Chl} \mathrm{m}^{-3}$, respectively.

Sampling of the "real world" was also skewed in time, with the majority of both the NODC records and the CZCS images taken from April 15 to November 31 (435 of the 566 NODC records and 327 of the 441 CZCS images). This is not just an artifact of this particular collection of CZCS images, as prior monthly composite pictures of oligotrophic regions during bloom periods have been based upon only one or two images collected during the month [Müller-Karger et al., 1991]. Since a significant portion of primary production in the North Atlantic occurs during this period, differences are sure to arise not only between the simulation and the images but also between other methods of calculating primary production and their relationship to CZCS images. Thus significant aliasing errors may occur when time series data obtained from satellite coverage are used [Walsh et al., 1987].

\subsection{Primary Production}

New, export, and total productions respond not only to the changing mixed layer depths but also to the frequency of the change (Table 2). Short-term forcing of the physical habitat raises estimates of both annual production and surface chlorophyll. Therefore using mean physical parameters to drive biological models (i.e., monthly averaged mixedlayer depths) may lead to inaccuracies in simulated carbon budgets.

High-frequency changes of the physical environment may partially explain the observed diversity of phytoplankton species [Hutchinson, 1961; Harris, 1980], since smoothing these events in this model altered nutrient introduction, primary production, and size composition of the phytoplankton assemblage. Both time series of CZCS images (Figure 2) and diatom blooms [Platt et al., 1989; Siegel et al., 1990] show cycles of the order of days. Thus the inclusion of high-frequency physical forcing in computer simulations may provide some reconciliation of the estimates of primary productivity by instantaneous uptake rates with those from bulk nutrient fluxes.

The results of the model match annual cycles of primary production and of vertical chlorophyll profiles [Menzel and Ryther, 1960; Ryther and Menzel, 1960; Prezelin and Glover, 1991; Lohrenz et al., 1992; Marra et al., 1992; A. F. Michaels et al., Ocean time-series measurements off of Bermuda: The first two years of the U.S. JGOFS Bermuda 
Atlantic Time-Series Study, submitted to Deep-Sea Research, 1993], including the summer subsurface chlorophyll maximum. Primary production of the picoplankton ranged from 21 to $42 \%$ of the total production (Table 2). A model of just one functional group of netplankton would have instead yielded a greater percentage of the total production during the spring. In addition, most of this model's picoplankton production occurred below the summer mixed layer. Attempts to model only the mixed layer would have neglected such production.

In an annual steady state, new production should equal nitrogen export [Eppley and Peterson, 1979]. Yet short-term variations of nitrogen export versus $\mathrm{NO}_{3}$ import, resulting from the interactions between the two phytoplankton functional groups, suggest that the nitrate-based "new" production for individual groups may not equal their separate nitrogen export. The increase of biomass of both functional groups is followed by an increase of ammonium at depth (Plates 1b and 2b) and covaries with the strength of the bloom of each functional group. During the summer, nitrate diffuses into the simulated summer euphotic zone, while particulate nitrogen in the form of picoplankton and ammonium diffuse out of the euphotic zone. Nitrogen leaving the euphotic zone in these forms effectively reduces the recycling efficiency $\left(\varepsilon_{i}\right)$ of the picoplankton and increases the nitrate-based contribution of total picoplankton production. Therefore the actual $f$ ratios (nitrate based production/total production; Table 2) for summer blooms of picoplankton are higher than the implicit $f$ ratio of 1 minus the recycling efficiency $\left(1-\varepsilon_{2}=1-0.8=0.2\right)$.

Deep mixing in late fall-early winter erodes the prior summertime accumulation of $\mathrm{NH}_{4}$, as water from the aphotic zone invades the nutrient-depleted euphotic zone. Such seasonal increases in nutrient concentrations spur the onset of netplankton dominance. Since a portion of the total nitrogen is in the form of $\mathrm{NH}_{4}$, the actual annual $f$ ratio for netplankton is lower than the implicit $f$ ratio $\left(1-\varepsilon_{1}=1-\right.$ $0.5=0.5$ ). It is important to note that the actual $f$ ratio is not fixed in this model and that it is a function of the functional group biomasses, grazing rates, recycling efficiencies, and mixing environment.

The model does not include heterotrophic bacteria, which can be just as important as phytoplankton in the uptake of $\mathrm{NH}_{4}$ [Harrison et al., 1992]. The model's production and ammonium stocks are both similar to actual measurements in oligotrophic regions near the surface [Sharp, 1983; Harrison et al., 1992]. At greater depths, the simulated $\mathrm{NH}_{4}$ levels are higher than observed levels [Brzezinski, 1988]; this result is to be expected in the absence of a heterotrophic microbial community.

Simple incorporation of $\mathrm{NH}_{4}$ uptake by heterotrophic bacteria would decrease both the total primary production and the ammonium stocks. Yet inclusion of bacteria as a state variable would allow us to modulate the grazing stress of zooflagellates on one of the existing functional groups (picoplankton), thereby maintaining the model's fidelity to primary production measurements. This situation clearly argues for increased complexity in biological models [Longhurst, 1991] at a number of different trophic levels, particularly within an oligotrophic environment [Fasham et al., 1990; Banse, 1991; Harrison et al., 1992].

It is unfortunate that one of the most significant parameters in the model is also one of the least understood. Grazing is the most significant loss term in this model, which may or may not be true in the real world. While we tried to use values in the available literature to bound our grazing rates, our simulation analysis confirms the pleas for further studies of higher trophic levels and their relation to global carbon budgets [Banse, 1991; Longhurst, 1991].

\subsection{Sedimentation}

Figure 8 shows the mean annual cycle of primary production over the 6-year period of case 1 . Comparison of this result with particle fluxes caught in long-term sediment traps at $3200 \mathrm{~m}$ during the same period finds an approximate 1.5-month lag between the peak primary production of the model and the maximum sediment trap collection [Deuser, 1986, Figure 5]. Our time lag is similar to the lag calculated by Deuser [1986] using $\delta^{18} \mathrm{O}$ measurements of Globigernoides ruber as records of surface temperature and mixed layer depth. Since the seasonal peak of depth-integrated grazing stress (and therefore export of larger particles) of the model closely follows the peak in primary production (Figure 5), this time lag implies that most particulate matter would have to sink out of the euphotic zone at approximately $70 \mathrm{~m} \mathrm{~d}^{-1}$ to reach a trap at $3200 \mathrm{~m}$, that is, at a rate similar to our implicit sinking rate of $>100 \mathrm{~m} \mathrm{~d}^{-1}$ for fecal pellets.

\section{Conclusions}

Increasing the temporal resolution, that is, incorporating higher-frequency variability, of the convective overturn of the water column increases the new, total, and export productivities of our model. A higher-frequency description of the mixing environment between 1979 and 1984 led to average annual differences of 6 and $4 \%$ for new and total production, respectively. Interannual differences of the highfrequency simulation were as much as $24 \%$ for new production and $15 \%$ for total production. These interannual variations result from increases in new and total production of $\mathbf{4 5}$ and $30 \%$, respectively, for the netplankton at the expense of picoplankton, owing to increased nutrient supply to the euphotic zone. These results show that some of the discrepancies between various estimates of primary productivity may be a function of temporal resolution of these estimates. This simulation is an example of the effects of highfrequency variability both on the behavior of an ecosystem and on our ability to observe the ecosystem.

Biogenic flux estimates of carbon and nitrogen presently smear over fluctuations of interdependent populations of primary and secondary producers. Increased resolution of these biological components will increase the accuracy of flux calculations for interpretation of field studies [Walsh et al., 1991]. This approach should be accompanied by modeling of the physical regime at higher frequencies to allow niche separation of the many species, or at least functional groups, of phytoplankton, zooplankton, and bacterioplankton. The effect would be to provide better reconciliation between disparate data sets of marine primary productivity and its role in global carbon cycles.

Grazing pressure represented the most significant loss of phytoplankton biomass in this model. This inadequately resolved closure of our model underlines calls for more studies of higher trophic levels in the real world [Banse, 1991; Longhurst, 1991]. Niche separation may be equally 
affected by differential grazing stresses on smaller organisms.

\section{Appendix: Model Formulation}

To determine daily maximum irradiance $\left(I_{\max }\right)$, daily solar declination angles were first calculated for $33^{\circ} \mathrm{N}, 63^{\circ} \mathrm{W}$; from these, daily values for the photoperiod (II) were then derived [Kirk, 1983]. Monthly solar radiation ( $\mathrm{W} \mathrm{m}^{-2}$ [Oberhuber, 1988]), assumed to integrate the effects of clouds on irradiance, was interpolated to daily values and converted to photosynthetically active radiation and microeinsteins $(\mu \mathrm{E})$ per square meter per second with factors of 0.50 and 4.15 , respectively [Morel and Smith, 1974]. A sine function was used to calculate the time dependence of light over the photoperiod:

$$
I(t)=I_{\max } \sin \left(\pi(t-a) \Pi^{-1}\right)
$$

where $t$ is the time step, and at sunrise $a=(12-0.5 \Pi)$.

Light is extinguished exponentially with depth as a function of attenuation by seawater and phytoplankton. The absorption coefficient for seawater $k_{w}$ was assumed to be $0.033 \mathrm{~m}^{-1}$, while the specific absorption coefficient was assumed to be $0.020 \mathrm{~m}^{2}(\mathrm{mg} \mathrm{Chl} a)^{-1}$ for the netplankton $\left(k_{c 1}\right)$ and $0.033 \mathrm{~m}^{2}(\mathrm{mg} \mathrm{Chl} a)^{-1}$ for the picoplankton $\left(k_{c 2}\right)$. These were converted into diffuse attenuation coefficients by assuming an inverse average cosine pathlength for light [Gordon and Morel, 1983]. Detritus and dissolved organic matter played no role in this model. The depth-dependent equation for light thus becomes

$$
I(z, t)=I(t) \exp \left[-1.25\left(k_{w} z+\sum_{i}^{2} k_{c, i} \int_{0}^{2} P_{i}(z) d z\right)\right]
$$

The time-dependent vertical eddy diffusivity in the surface mixed layer $K_{0}$ is a function of the wind stress $\tau_{s}$ and the Coriolis parameter $f$ at the appropriate latitude [Csanady, 1976; Kullenberg, 1976]:

$$
K_{0}=4.9 \times 10^{-3} \tau_{s} f^{-1}
$$

The wind stress, in turn, was derived from the Hellerman and Rosenstein [1983] formulation of a drag coefficient, scalar wind $W$, and the density of air $\rho_{a}\left(1 \times 10^{-3} \mathrm{~g} \mathrm{ml}^{-1}\right)$ :

$$
\begin{aligned}
\tau_{s}=\rho_{a}( & 0.934 \times 10^{-3}+0.788 \times 10^{-3} W \\
- & \left.0.616 \times 10^{-6} W^{2}\right) W^{2}
\end{aligned}
$$

Scalar wind was interpolated daily from monthly averages at the appropriate latitude and longitude [Wright, 1988].

The vertical eddy diffusivity below the surface mixed layer $\left(K_{m}\right)$ was set to a constant $8.0 \mathrm{~cm}^{2} \mathrm{~s}^{-1}$. This value was determined by running the model to steady state (the point at which the annual changes of the state variables were $<0.01 \%$ ), using the mixed-layer depths from the NODC records during 1985 and 1986, to yield an average $\mathrm{NO}_{3}$ flux of $0.58 \mathrm{~mol} \mathrm{~N} \mathrm{~m}^{-2} \mathrm{yr}^{-1}$ into the euphotic zone. This $\mathrm{NO}_{3}$ flux is equal to that calculated by Jenkins [1988] in the same area for the same time period.

Such a vertical eddy diffusivity, below the surface mixed layer, is larger than other estimates of 0.1 to $0.5 \mathrm{~cm}^{2} \mathrm{~s}^{-1}$
[Gargett, 1984] but may reflect both horizontal and vertical motions, which are not explicitly resolved by a onedimensional physical model. Integrating nitrogen fluxes at $100 \mathrm{~m}$, Altabet [1989] calculated a range of vertical eddy diffusivities of 0.3 to $21.3 \mathrm{~cm}^{2} \mathrm{~s}^{-1}$ when the mixed layer was shallower than $80 \mathrm{~m}$. Our value of $8 \mathrm{~cm}^{2} \mathrm{~s}^{-1}$ may thus be a reasonable assumption for a one-dimensional model in this region of the Sargasso Sea.

The state equations for netplankton $P_{1}$ and picoplankton $P_{2}$,

$$
\begin{gathered}
\frac{\partial P_{1}}{\partial t}=\mu_{m} \min \left[\tanh \left(\frac{\alpha I(z, t)}{\mu_{m}}\right), \frac{N}{k_{N}+N} e^{-\Psi A}\right. \\
\left.+\frac{A}{k_{A}+A}\right] P_{1}-\frac{g_{m}}{k_{g}+P_{1}} P_{1}+\frac{\partial}{\partial z} K_{z} \frac{\partial P_{1}}{\partial z}-w_{s P_{1}} \frac{\partial P_{1}}{\partial z} \\
\frac{\partial P_{2}}{\partial t}=\mu_{m} \min \left[\tanh \left(\frac{\alpha I(z, t)}{\mu_{m}}\right), \frac{N}{k_{N}+N} e^{-\Psi A}\right. \\
\left.+\frac{A}{k_{A}+A}\right] P_{2}-g P_{2}+\frac{\partial}{\partial z} K_{z} \frac{\partial P_{2}}{\partial z}-w_{s P_{2}} \frac{\partial P_{2}}{\partial z}
\end{gathered}
$$

assume that algal growth is limited by a single factor, either light $I$ or total nitrogen, at any given depth and time. Values for these parameters are given in Table 1.

The state equations for nitrate and ammonium are

$$
\begin{gathered}
\frac{\partial N}{\partial t}=-\sum a_{N_{i} P_{i}}+\frac{\partial}{\partial z} K_{z} \frac{\partial N}{\partial z} \\
\frac{\partial A}{\partial t}=-\sum a_{A_{i}} P_{i}+\varepsilon_{1}\left(\frac{g_{m} P_{1}}{k_{g}+P_{1}}\right)+\varepsilon_{2} g P_{2}+\frac{\partial}{\partial z} K_{z} \frac{\partial A}{\partial z}
\end{gathered}
$$

where the functions $a_{N_{1}}$ in (7) and $a_{A_{i}}$ in (8) refer to that portion of the total algal growth demand supplied by $\mathrm{NO}_{3}$ and $\mathrm{NH}_{4}$, respectively, for each functional group. In the nitrogen uptake expression, ammonium is preferentially assimilated on the basis of energetic considerations. $\Psi$ is 1.5 $\mu \mathrm{m}^{-1}$ [Wroblewski, 1977], which allows inhibition of nitrate uptake at increasing concentrations of $\mathrm{NH}_{4}$. The halfsaturation constant of oligotrophic phytoplankton is $0.05 \mu \mathrm{M}$ for $\mathrm{NH}_{4}\left(k_{A}\right)$ and $0.10 \mu \mathrm{M}$ for $\mathrm{NO}_{3}\left(k_{N}\right)$ according to Eppley et al. [1977].

With respect to differences of nutrient uptake between the functional groups, smaller spherical cells have an advantage, with respect to the diffusive supply rate from the cell surface, over larger spheres. However, large cells in oligotrophic regions have adapted to nonspheroidal shapes, thus increasing surface area in relation to volume [Chisholm, 1992]. Given this fact and the problematic assessment of nutrient kinetics at and below the conventional detection levels for nitrogen, we chose not to make any further distinction based on nutrient kinetics in this model but to define competition by other factors.

The netplankton growth rate was assumed to be higher than that of the picoplankton, in accordance with laboratory studies of maximum growth rates $\left(\mu_{m}\right)$ among various oceanic phytoplankton taxa [Brand and Guillard, 1981]. Maximum netplankton growth rate (carbon specific) was taken to be $2.773 \mathrm{day}^{-1}$, or 4.0 doublings $\mathrm{d}^{-1}$ [Brand and 
Guillard, 1981]; maximum picoplankton growth rate was $1.386 \mathrm{~d}^{-1}$, or 2.0 doublings $\mathrm{d}^{-1}$ [Bienfang and Takahashi, 1983; Kana and Glibert, 1987; Iturriaga and Marra, 1988]. While these were the maximum growth rates, actual growth rates for both functional groups did not exceed $0.63 \mathrm{~d}^{-1}$, or 0.9 doublings $\mathrm{d}^{-1}$, owing to either light or nutrient limitation.

Photosynthetic efficiency can be described as $\alpha=\Phi_{m} k_{c i}$, with $\Phi_{m}$ as the maximum quantum yield of photosynthesis (moles $C$ per mole quanta) and $k_{c i}$ (where $i$ is the index of phytoplankton functional group) as the absorption coefficient for each functional group. The minimum amount of light energy needed to fix $1 \mathrm{~mol}$ of $\mathrm{C}$ is equivalent to 8-10 $\mathrm{E}$, though the practical limit may be closer to $12 \mathrm{E}$ as a result of slippage/leakage processes in energy transduction [Kirk, 1983; Geider et al., 1986]. Experimental values for $\Phi_{m}^{-1}$ range from approximately 11 to 22 [Sakshaug et al., 1991]; it was set to 12 for both the netplankton and the picoplankton.

Photosynthetic efficiency $\alpha$ is converted to the more conventional form of $\mathrm{mg} \mathrm{C} \mathrm{mg} \mathrm{Chl}{ }^{-1} \mathrm{~h}^{-1}\left[\mu \mathrm{E} \mathrm{m}^{-2} \mathrm{~s}^{-1}\right]^{-1}$ with a conversion constant of $43.2\left(12000 \mathrm{mg} \mathrm{C} \mathrm{mol} \mathrm{C}^{-1} \times\right.$

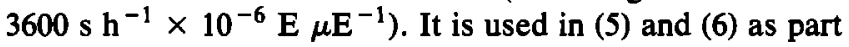
of a hyperbolic tangent function of the photosynthesisirradiance relationship [Jassby and Platt, 1976]. Picoplankton have an intrinsic light-harvesting advantage (greater absorption coefficient, or $k_{c 1}>k_{c 2}$ ) as a result of the reduced packaging effects of their pigment arrangements [Kirk, 1983] and therefore are more efficient at low light (Table 1).

The grazing terms assume a single type of herbivore for each phytoplankton functional group. For netplankton, ingestion is modeled as a rectangular hyperbolic function [Mullin et al., 1975]. The half-saturation constant $k_{g}$ was set to $1.0 \mathrm{mg} \mathrm{Chl} \mathrm{m}{ }^{-3}$, so that most concentrations of chlorophyll fell in the near-linear portion of the curve at typical netplankton densities. The slope $m$ of the grazing stress in this region was determined by parameter evaluation to be $5.5 \%$ of $\mu_{m}$. The maximum grazing rate $g_{m}$ is determined by recalling that $g=0.5 g_{m}$ at the half-saturation concentration of $k_{g}$. The slope $m$ of the linear portion of the rectangular hyperbolic function is then equal to $0.5 g_{m} / k_{g}$; thus $g_{m}=$ $2 m k_{g}$.

A note on parameter evaluation is relevant at this point. Given the large number of parameters and the sometimes wide range of measured values for them, we first chose "reasonable" values from the literature. Parameter evaluation, or "tuning," was then conducted on those processes, particularly grazing, for which little published information was available.

Specifically, we ran the model with different values for the slope of the grazing stress on the netplankton to achieve coexistence of the phytoplankton groups. Because (1) grazing pressure represented the most significant loss in our model and (2) it was the function with the least amount of data in the literature, we also advocate more studies of higher trophic levels in the real world [e.g., Banse, 1991; Longhurst, 1991]. We stress the significance of this term and the fact that the character of the simulation results depends on the type of closure used for the system of equations [Steele and Henderson, 1992].

In the case of the picoplankton, grazing was instead assumed to be by rapidly growing protozoan herbivores within a tightly coupled system. This type of grazing was modeled with a first-order loss term, where $g$, in this case, is a mass specific rate constant; it was determined to be $\mathbf{0 . 1 8}$ $\mu_{m}$, which is within the range of values reported by Iturriaga and Marra [1988]. Refuge populations were set at $1 \times 10^{3}$ cells $\mathrm{L}^{-1}$ for netplankton and $4 \times 10^{6}$ cells $\mathrm{L}^{-1}$ for picoplankton; below these limits, no grazing occurred. Abundances of cells $\mathrm{L}^{-1}$ were converted to biomasses of chlorophyll $\mathrm{L}^{-1}$, with conversion factors of $1 \times 10^{-9} \mathrm{mg} \mathrm{Chl} \mathrm{cell}^{-1}$ for netplankton and $1 \times 10^{-12} \mathrm{mg} \mathrm{Chl} \mathrm{cell}{ }^{-1}$ for picoplankton.

Nitrogen biomass was recycled immediately into $\mathrm{NH}_{4}$ at recycling efficiencies $\varepsilon_{1}$ for netplankton and $\varepsilon_{2}$ for picoplankton. The remainder $\left(1-\varepsilon_{i}\right)$, where $i$ is the index for the functional group, is assumed to be exported from the model as rapidly sinking particulate matter, for example, fecal pellets. Michaels and Silver [1988] modeled the range of probabilities that nitrogen incorporated into various phytoplankton groups would ultimately be exported; the probabilities varied from 4 to $19 \%$ for picoplankton and 30 to $65 \%$ for netplankton.

These estimates of export translate into recycling efficiencies of 96 to $81 \%$ for picoplankton and 70 to $35 \%$ for netplankton. Fasham et al. [1990] had an effective ammonium recycling efficiency of $56 \%$ (75\% assimilation efficiency $\times 75 \%$ ammonium excretion rate) in modeling bulk phytoplankton populations within the surface mixed layer. Here we chose netplankton nitrogen recycling $\varepsilon_{1}$ to be $50 \%$, compared to $80 \%$ for picoplankton nitrogen recycling $\varepsilon_{2}$.

The last term in the phytoplankton state equations is the sinking flux. The sinking rate is taken to be $1.5 \mathrm{~m} \mathrm{~d}^{-1}\left(w_{s 1}\right)$ for netplankton [Bienfang, 1980] and $0.0 \mathrm{~m} \mathrm{~d}^{-1}\left(w_{s 2}\right)$ for picoplankton [Takahashi and Bienfang, 1983]. The fecal pellet flux is not explicitly simulated, but a daily grazing export of $1-\varepsilon_{i}$ from the euphotic zone implies a sinking rate of $>100 \mathrm{~m} \mathrm{~d}^{-1}$.

Finally, the two algal groups also have different $C: C h l$ ratios, which impact the amount of nitrogen removed by each group at each time step, because nitrogen is assumed to be fixed at a constant $C: N$ ratio of $6.625 \mathrm{~mol} \mathrm{~mol}^{-1}$. The C:Chl ratio for picoplankton is 30:1 [Glover et al., 1988], while it is 50:1 for the netplankton [Eppley et al., 1977].

Fluxes at the sea surface are defined as

$$
K_{z} \frac{\partial P_{i}}{\partial z}=K_{z} \frac{\partial N}{\partial z}=K_{z} \frac{\partial A}{\partial z}=0
$$

The boundary conditions for each functional group and ammonium at the base of the model (a depth of $450 \mathrm{~m}$ ) are equal to $0.0 \mathrm{mg} \mathrm{Chl} \mathrm{m}{ }^{-3}$ and $0.0 \mu M \mathrm{NH}_{4}$. Nitrate at the base of the model is $8 \mu M \mathrm{NO}_{3}$. Diffusive fluxes are allowed for all of the state variables at the bottom boundary in addition to the particulate flux of the two algal components.

Initial conditions for nitrate and total chlorophyll are taken from the United States Joint Global Ocean Flux Study at the Bermuda Atlantic Time Series station [U.S. JGOFS, 1990], while that of $\mathrm{NH}_{4}$ was assumed to be $10 \%$ of the $\mathrm{NO}_{3}$ concentration [Sharp, 1983]. The total chlorophyll concentration was then split between the functional groups, with $\mathbf{7 0 \%}$ for netplankton and $30 \%$ for picoplankton, reflectirg a fall phytoplankton assemblage. The model was run for 5 years, using the 1979 daily mixed layer depth profiles to achieve steady state $(<0.01 \%$ change in the state variables) before continuing with the other mixed layer depths from 1980 to 1984. 
The diffusion terms were solved explicitly with a forwardin-time, centered-in-space method [O'Brien, 1986]. The von Neumann stability condition for the diffusion terms in (5)-(8) is $2 \Delta t K_{z} / \Delta z^{2} \leq 1$. For a maximum $K_{z}$ of $\approx 100 \mathrm{~cm}^{2} \mathrm{~s}^{-1}$ from (3) and a $\Delta z$ of $10 \mathrm{~m}$, a $\Delta t$ time step of only $\leq 1.4$ hours would be required for numerical stability.

However, the remaining biological terms were also solved explicitly with a forward-in-time method. The nitrogen uptake terms, with their low half-saturation constants, place an additional restriction on the time step; under certain conditions for large $\Delta t$, nitrogen demand can outstrip nitrogen supply. While a $\Delta t$ of 1 hour is possible with a single algal component [Walsh et al., 1989], this two-component model required a shorter time step. The time step was thus $900 \mathrm{~s}$, satisfying both biological and von Neumann stability conditions.

Finally, the particulate settling terms of (5) and (6) were solved with a modified upwind difference technique [Smolarkiewicz, 1983]. This method applies a correction for the artificial viscosity, or numerical diffusion, which results from the upwind difference scheme by forming an antidiffusion velocity from the estimated artificial viscosity.

Acknowledgments. We would like to thank Dwight Dieterle for his support in the development of the model. This research was supported by the National Aeronautics and Space Administration under grants NAGW-678 and NAGW-3459.

\section{References}

Altabet, M. A., Particulate new nitrogen fluxes in the Sargasso Sea, J. Geophys. Res., 94, 12,771-12,779, 1989.

Banse, K., False advertising in the greenhouse?, Global Biochemic. Cycles, 5, 305-307, 1991.

Bienfang, P. K., Phytoplankton sinking rates in oligotrophic waters off Hawaii, USA, Mar. Biol., 61, 69-77, 1980.

Bienfang, P. K., and M. Takahashi, Ultraplankton growth rates in a subtropical ecosystem, Mar. Biol., 76, 213-218, 1983.

Brand, L. E., and R. R. L. Guillard, The effects of continuous light and light intensity on the reproduction rates of twenty-two species of marine phytoplankton, J. Exp. Mar. Biol. Ecol., 50, 119-132, 1981.

Brzezinski, M. A., Vertical distribution of ammonium in stratified oligotrophic waters, Limnol. Oceanogr., 33, 1176-1182, 1988.

Chisholm, S. W., Phytoplankton size, in Primary Productivity and Biogeochemical Cycles in the Sea, edited by P. G. Falkowski and A. D. Woodhead, pp. 213-237, Plenum, New York, 1992.

Csanady, G. T., Mean circulation in shallow seas, J. Geophys. Res., 81, 5389-5399, 1976.

Deuser, W. G., Seasonal and interannual variation in deep-water particle fluxes in the Sargasso Sea and their relation to surface hydrography, Deep Sea Res., 33, 225-246, 1986.

Deuser, W. G., F. E. Müller-Karger, R. H. Evans, O. B. Brown, W. E. Esaias, and G. C. Feldman, Surface-ocean color and deep-ocean carbon flux: How close a connection?, Deep Sea Res., 37, 1331-1343, 1990.

Eppley, R. W., and B. J. Peterson, Particulate organic matter flux and planktonic new production in the deep ocean, Nature, 282, 677-680, 1979.

Eppley, R. W., J. H. Sharp, E. H. Renger, M. J. Perry, and W. G. Harrison, Nitrogen assimilation by phytoplankton and other microorganisms in the surface waters of the North Pacific Ocean, Mar. Biol., 39, 111-120, 1977.

Eppley, R. W., E. H. Renger, and P. R. Betzer, The residence time of particulate organic carbon in the surface layer of the ocean, Deep Sea Res., 30, 311-323, 1983.

Eppley, R. W., E. Stewart, M. R. Abbott, and U. Heyman, Estimating ocean primary production from satellite chlorophyll: Introduction to regional differences and statistics for the Southern California Bight, J. Plankton Res., 7, 57-70, 1985.
Fasham, M. J. R., H. W. Ducklow, and S. M. McKelvie, A nitrogen-based model of plankton dynamics in the oceanic mixed layer, J. Mar. Res., 48, 591-639, 1990.

Gargett, A. E., Vertical eddy diffusivity in the ocean interior, $J$. Mar. Res., 42, 359-393, 1984.

Geider, R. J., B. A. Osborne, and J. A. Raven, Growth, photosynthesis and maintenance metabolic cost in the diatom Phaeodactylum tricornutum at very low light levels, J. Phycol., 22, 39-48, 1986.

Glover, H. E., B. P. Prezelin, L. Campell, M. Wyman, and C. Garside, A nitrate-dependent Synechococcus bloom in surface Sargasso Sea water, Nature, 331, 161-163, 1988.

Gordon, H. R., and A. Y. Morel, Remote assessment of ocean color for interpretation of satellite visible imagery-A review, Lect. Notes Coastal Estuarine Stud., 1-144, 1983.

Gordon, H. R., D. K. Clark, J. W. Brown, O. B. Brown, R. H. Evans, and W. W. Broenkow, Phytoplankton pigment concentration in the Middle Atlantic Bight: Comparison of ship determinations and CZCS estimates, Appl. Opt., 22, 20-35, 1983a.

Gordon, H. R., J. W. Brown, O. B. Brown, R. H. Evans, and D. K. Clark, Nimbus 7 CZCS: Reduction of its radiometric sensitivity with time, Appl. Opt., 22, 3929-3931, 1983b.

Gregg, W. W., and J. J. Walsh, Simulation of the 1979 spring bloom in the Mid-Atlantic Bight: A coupled physical/biological/optical model, J. Geophys. Res., 97, 5723-5743, 1992.

Harris, G. P., Temporal and spatial scales in phytoplankton ecology: Mechanisms, methods, models, and management, Can. J. Fish. Aquat. Sci., 37, 877-900, 1980.

Harrison, W. G., L. R. Harris, D. M. Karl, G. A. Knauer, and D. G. Redalje, Nitrogen dynamics at the VERTEX time-series site, Deep Sea Res., 39, 1535-1552, 1992.

Hellerman, S., and M. Rosenstein, Normal monthly wind stress over the world ocean with error estimates, J. Phys. Oceanogr., 13, 1093-1104, 1983.

Hulburt, E. M., Description of phytoplankton and nutrient in spring in the western North Atlantic Ocean, J. Plankton Res., 12, 1-28, 1990.

Hutchinson, G. E., The paradox of the plankton, Am. Nat., 882, $137-145,1961$.

Iturriaga, R., and J. Marra, Temporal and spatial variability of chroococcoid cyanobacteria Synechococcus spp. specific growth rates and their contribution to primary production in the Sargasso Sea, Mar. Ecol. Prog. Ser., 44, 175-181, 1988.

Jassby, A. D., and T. Platt, Mathematical formulation of the relationship between photosynthesis and light for phytoplankton, Limnol. Oceanogr., 21, 540-547, 1976.

Jenkins, W. C., and J. C. Goldman, Seasonal oxygen cycling and primary production in the Sargasso Sea, J. Mar. Res., 43, 465-491, 1985.

Jenkins, W. J., Nitrate flux into the euphotic zone near Bermuda, Nature, 331, 521-523, 1988.

Kana, T. M., and P. M. Glibert, Effect of irradiances up to $2000 \mu \mathrm{E}$ $\mathrm{m}^{-2} \mathrm{~s}^{-1}$ on marine Synechococcus WH7803, I, Growth, pigmentation, and cell composition, Deep Sea Res., 34, 479-495, 1987.

Kirk, J. T. O., Light and Photosynthesis in Aquatic Environments, 399 pp., Cambridge University Press, New York, 1983.

Klein, P., and B. Coste, Effects of wind-stress variability on the nutrient transport into the mixed layer, Deep Sea Res., 31, 21-37, 1984.

Kullenberg, G. E., On vertical mixing and the energy transfer from wind to water, Tellus, 28, 159-165, 1976.

Levitus, S., Climatological Atlas of the World Ocean, NOAA Prof. Pap. 13, 173 pp., U.S. Govt. Print. Off., Washington, D. C., 1982.

Lohrenz, S. E., G. A. Knauer, V. L. Asper, M. Tuel, A. F. Michaels, and A. H. Knap, Seasonal variability in primary production and particle flux in the northwestern Sargasso Sea: U.S. JGOFS Bermuda Atlantic time-series study, Deep Sea Res., 39, 1373-1391, 1992.

Longhurst, A. R., Role of the marine biosphere in the global carbon cycle, Limnol. Oceanogr., 36, 1507-1526, 1991.

Marra, J., et al., Estimation of seasonal primary production from moored optical sensors in the Sargasso Sea, J. Geophys. Res., 97, 7399-7412, 1992.

Martin, J. H., G. A. Knauer, D. M. Karl, and W. W. Broenkow, VERTEX: Carbon cycling in the northeast Pacific, Deep Sea Res., 34, 267-285, 1987. 
Menzel, D. W., and J. H. Ryther, The annual cycle of primary production in the Sargasso Sea off Bermuda, Deep Sea Res., 6, 351-367, 1960.

Menzel, D. W., E. M. Hulburt, and J. H. Ryther, The effects of enriching Sargasso Sea water on the production and species composition of the phytoplankton, Deep Sea Res., 10, 209-219, 1963.

Michaels, A. F., and M. W. Silver, Primary production, sinking fluxes and the microbial food web, Deep Sea Res., 35, 473-490, 1988 .

Morel, A., and R. C. Smith, Relation between total quanta and total energy for aquatic photosynthesis, Limnol. Oceanogr., 19, 591$600,1974$.

Müller-Karger, F. E., J. J. Walsh, R. H. Evans, and M. B. Meyers, On the seasonal phytoplankton concentration and sea surface temperature cycles of the Gulf of Mexico as determined by satellites, J. Geophys. Res., 96, 12,645-12,665, 1991.

Mullin, M. M., E. F. Stewart, and F. J. Fuglister, Ingestion by plankton grazers as a function of concentration of food, Limnol. Oceanogr., 20, 259-262, 1975.

Musgrave, D. L., J. Chou, and W. J. Jenkins, Application of a model of upper-ocean physics for studying seasonal cycles of oxygen, J. Geophys. Res., 93, 15,679-15,700, 1988.

National Oceanographic Data Center (NODC), Global Ocean Temperature and Salinity Profiles, Informal Rep. 12, pp. 1-14, Natl. Oceanogr. Data Cent., Washington, D. C., 1991.

Oberhuber, J. M., An atlas based on the 'COADS' data set: The budgets of heat, buoyancy and turbulent kinetic energy at the surface of the global ocean, Rep. 15, pp. 1-19, Max Planck Inst. for Meteorol., Hamburg, Germany, 1988.

O'Brien, J. J., The diffusive problem, in Advanced Physical Oceanographic Numerical Modelling, edited by J. J. O'Brien, pp. 127-144, D. Reidel, Norwell, Mass., 1986.

Olson, R. J., S. W. Chisholm, E. R. Zeittler, M. A. Altabet, and J. A. Dusenberry, Spatial and temporal distributions of prochlorophyte and picoplankton in the North Atlantic Ocean, Deep Sea Res., 37, 1033-1051, 1990.

Platt, T., and W. G. Harrison, Biogenic fluxes of carbon and oxygen in the ocean, Nature, 318, 55-58, 1985.

Platt, T., and W. G. Harrison, Reconciliation of carbon and oxygen fluxes in the upper ocean, Deep Sea Res., 2, 273-276, 1986.

Platt, T., W. G. Harrison, M. R. Lewis, W. K. W. Li, S. Sathyendranath, R. E. Smith, and A. F. Vezina, Biological production of the oceans: The case for a consensus, Mar. Ecol. Prog. Ser., 52, 77-88, 1989.

Platt, T., C. Caverhill, and S. Sathyendranath, Basin-scale estimates of oceanic primary production by remote sensing: The North Atlantic, J. Geophys. Res., 96, 15,147-15,159, 1991.

Prezelin, B. B., and H. E. Glover, Variability in time/space estimates of phytoplankton, biomass and productivity in the Sargasso Sea, J. Plankton Res., 13, 45-67, 1991.

Ryther, J. H., and D. W. Menzel, The seasonal and geographical range of primary production in the western Sargasso Sea, Deep Sea Res., 6, 235-238, 1960.

Sakshaug, E., G. Johnson, K. Anderson, and M. Vernet, Modeling of light-dependent algal photosynthesis and growth: Experiments with the Barents Sea diatoms Thalassiosira nordenskioeldii and Chaetocerus furcellatus, Limnol. Oceanogr., 38, 415-430, 1991.

Sharp, J. H., Distribution of inorganic and organic nitrogen in the sea, in Nitrogen in the Marine Environment, edited by E. J.
Carpenter and D. G. Carpone, pp. 1-35, Academic, San Diego, Calif., 1983.

Siegel, D. A., R. Iturriaga, R. R. Bidigare, R. C. Smith, H. Pak, T. D. Dickey, J. Marra, and K. S. Baker, Meridional variations of the springtime phytoplankton community in the Sargasso Sea, $J$. Mar. Res., 48, 379-412, 1990.

Smolarkiewicz, P. K., A simple positive definite scheme with small implicit diffusion, Mon. Weather Rev., 111, 479-486, 1983.

Spitzer, W. S., and W. J. Jenkins, Rates of vertical mixing, gas exchange and new production: Estimates from seasonal gas cycles in the upper ocean near Bermuda, J. Mar. Res., 47, 169-196, 1989.

Steele, J. H., and E. W. Henderson, The role of predation in plankton models, J. Plankton Res., 14, 157-172, 1992.

Takahashi, M., and P. K. Bienfang, Size structure of phytoplankton biomass and photosynthesis in subtropical Hawaiian waters, Mar. Biol., 76, 203-211, 1983.

Taylor, A. H., A. J. Watson, M. Ainsworth, J. E. Robertson, and D. R. Turner, A modelling investigation of the role of phytoplankton in the balance of carbon at the surface of the North Atlantic, Global Biogeochem. Cycles, 5, 151-171, 1991.

United States Joint Global Ocean Flux Study (U.S. JGOFS) Bermuda Atlantic Time-Series Study Data Report B-1, 110 pp., U.S. JGOFS Planning and Coordination Office, Woods Hole Oceanographic Institution, Woods Hole, Mass., 1990.

Walsh, J. J., D. A. Dieterle, and W. E. Esaias, Satellite detection of phytoplankton export from the mid-Atlantic Bight during the 1979 spring bloom, Deep Sea Res., 34, 675-703, 1987.

Walsh, J. J., D. A. Dieterle, M. B. Meyers, and F. E. MüllerKarger, Nitrogen exchange at the continental margin: A numerical study of the Gulf of Mexico, Prog. Oceanogr., 23, 245-301, 1989.

Walsh, J. J., D. A. Dieterle, and J. R. Pribble, Organic debris on the continental margins: A simulations analysis of source and fate, Deep Sea Res., 38, 805-828, 1991.

Williams, P. J. L., and D. A. Purdie, In vitro and in situ derived rates of gross production, net community production and respiration of oxygen in the oligotrophic subtropical gyre of the North Pacific Ocean, Deep Sea Res., 38, 891-910, 1991.

Wright, P. B., An atlas based on the 'COADS' data set: Fields of mean wind, cloudiness and humidity at the surface global ocean, Rep. 14, Max Planck Inst. for Meteorol., Hamburg, Germany, 1988.

Wroblewski, J. S., A model of phytoplankton plume formation during variable Oregon upwelling, J. Mar. Res., 35, 357-394, 1977.

Wroblewski, J. S. J. L. Sarmiento, and G. R. Flierl, An ocean basin scale model of plankton dynamics in the North Atlantic, 1 Solutions for the climatological oceanographic conditions in May, Global Biogeochem. Cycles, 2, 199-218, 1988.

W. P. Bissett, F. E. Müller-Karger, and J. J. Walsh, Department of Marine Science, University of South Florida, St. Petersburg, FL 33701 .

M. B. Meyers, Virginia Institute of Marine Science, P.O. Box 1346, Gloucester Point, VA 23062-1346.

(Received November 19, 1992; revised October 7, 1993; accepted November 9, 1993.) 